\title{
Seasonal variations of natural products in European herbs
}

\author{
Yan Li $\cdot$ Christian Zidorn
}

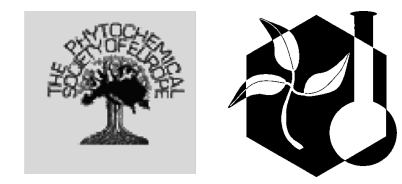

Received: 23 August 2021 / Accepted: 17 December 2021 / Published online: 10 January 2022

(C) The Author(s) 2022

\begin{abstract}
The present review gives an overview about the status of research on seasonal variation of natural products in herbs growing in or grown in Europe. Due to pronounced differences in weather patterns, papers covering plants from the Mediterranean, the temperate, and the cold climate zones are reviewed separately. Apart from trying to give an overview of the existing newer literature after the year 2000 , we try to identify some repeatedly found seasonal trends and discuss some possible explanations for these trends. Moreover, some suggestions, which encompass both research bias and desirable quality standards concerning experimental designs for future studies, are given. The covered investigations are mainly focused on aerial parts and leaves. Some publications are also dealing with flowers and roots. The composition of essential oils of aromatic plants are particularly well investigated. Phenolics are the most often studied compound class, including different types of phenolic acids, flavonoids, and tannins. Additionally, some papers assess the seasonal variation of alkaloids and lipophilic compounds.
\end{abstract}

Keywords Herbs - Natural products - Seasonal variation $\cdot$ Climate zones $\cdot$ Chemical ecology

Y. Li · C. Zidorn $(\bowtie)$

Pharmazeutisches Institut, Abteilung Pharmazeutische

Biologie, Christian-Albrechts-Universität zu Kiel,

Gutenbergstraße 76, 24118 Kiel, Germany

e-mail: czidorn@pharmazie.uni-kiel.de

\section{Introduction}

Living plants are intimately linked to their environment and thus strongly influenced by climatic factors. Many plant taxa used as medicines, spices, and food plants are herbs. The seasonal variation of active ingredients in these herbs, both desired as active ingredients and unwanted as toxins or off-taste producing compounds, is well known in folk lore. Nonetheless, scientifically this topic has not been exhaustively studied yet. There are, however, a number of literature reports focusing on seasonal variation of plant natural products. Unfortunately, not all papers published in this field use adequate analytical methods and sampling methodologies. Therefore, not all papers published in this broad field have been included in the current review. We were particularly interested in high quality papers with adequate analytical methods and a well-defined sampling protocol. One of our aims was to compare the found trends with the trends previously described trends for trees in Europe (Zidorn 2018). An additional focus was to reveal potential differences between different climate zones.

Literature was searched using the keywords "seasonal variation", "seasonal changes" in combination with "natural products", and "herbs" in the Google Scholar, Sci Finder, and Web of Science databases from August to November 2020. Only papers dealing with herbs growing/grown in an open-air environment 
were included; thus, studies on plants grown in green houses or culture media were not reviewed. Also, manuscripts covering too short time spans, i.e. less than at least two seasons were excluded.

In order to keep the review within manageable limits, we have restricted this review to Europe and its three main climatic zones, Mediterranean, temperate, and cold climates. The climate classification map (Fig. 1) of Europe from the EEA (European Environment Agency) shows that the dominant climate type in European area is temperate, followed by cold and subtropical. However, without changing the area indicated in the map, we use in the following text the term Mediterranean climate for the climate prevailing in the South of Europe, around the Mediterranean, and in the West of the Iberian Peninsula. In the following sections, annual and perennials herbs on the one hand and sub/under-shrubs are discussed separately.

In the present review, the focus is on recent papers (published year $\geq 2000$ ), using modern analytical techniques like GC/GC-MS, HPLC/LC-MS, and qNMR. Using the criteria explained above, 52 papers were selected. Though this number is not as high as desired when we started our work, we are confident that some general conclusions still can be drawn. In the following sections, all the binomial names are checked and revised according to World Flora Online, e.g., several former members of Clusiaceae/Guttiferae are now placed in the Hypericaceae family; Calamintha nepeta (L.) Savi is a synonym of Clinopodium nepeta (L.) Kuntze. If the binomial names could not be found in World Flora Online, author citations from the original publications for scientific species names were kept, e.g. Hypericum perforatum subspecies angustifolium (DC.) Gaudin and veronense (Schrank) Frolich.

The data edited below include 38 articles studying seasonal variation of European herbs in a total of 29 genera and 15 families. Fifteen reports are dealing with herbs from the Mediterranean climate zone from thirteen genera (Artemisia, Calendula, Clinopodium, Foeniculum, Helichrysum, Hypericum, Micromeria, Origanum, Ruta, Satureja, Scrophularia, Thymbra, and Thymus) belonging to six families (Apiaceae, Asteraceae, Fabaceae, Hypericaceae, Lamiaceae, Rutaceae, and Scrophulariaceae). Twenty-one reports deal with herbs from the temperate climate zone and encompass nineteen genera (Alchemilla, Antirrhinum, Artemisia, Barbarea, Clinopodium, Echinacea,
Fig. 1 Main climates of Europe, Mediterranean, temperate, and cold climates. The map was drawn by European Environment Agency (https://www.eea.europa.eu/data-and-maps/figures/ climate)

Gentiana, Glechoma, Glycyrrhiza, Hypericum, Macleaya, Medicago, Melittis, Mentha, Narcissus, Pulmonaria, Satureja, Stylophorum, and Thymus) from eleven families (Amaryllidaceae, Asteraceae, Boraginaceae, Brassicaceae, Fabaceae, Gentianaceae, Hypericaceae, Lamiaceae, Papaveraceae, Plantaginaceae, and Rosaceae). Two reports are concerning herbs species from the cold zone from two genera Corydalis (Papaveraceae) and Geranium (Geraniaceae) (Table 1). Regarding shrubs, fourteen articles were selected, these deal with five genera from three families. Ten reports are concerning sub-shrubs and shrubs from the Mediterranean climate zone encompassing five genera (Digitalis, Hypericum, Rosmarinus, Salvia, and Thymus) from three families (Hypericaceae, Lamiaceae, and Plantaginaceae). Four reports focus on sub-shrubs from temperate climates, these cover species from two genera (Rosmarinus and Salvia), both from the Lamiaceae family (Table 2).

\section{Factors relevant for seasonal changes in plant natural products}

Various genetic, ontogenic, morphogenetic, and environmental factors can influence the biosynthesis and accumulation of natural products. While herbs develop and grow, they follow a series of predictable and recognizable stages: the seedling stage, vegetative stage, flowering stage, fruiting stage, and finally senescence. During these changes of ontogenetic and morphological stages, the content of natural products often changes dramatically. These changes can be partially explained by the allocation theory and by pressure from herbivores (Barton and Koricheva 2010; Boege and Marquis 2005). On the other hand, natural products can be biosynthesized gradually in response to environmental stress. In this context, temperature, radiation, water availability, and other factors have been proven to have an impact. Simultaneously, all these factors change with time and thus synergistically change during the growing season. Therefore, seasonal variation comprises several 


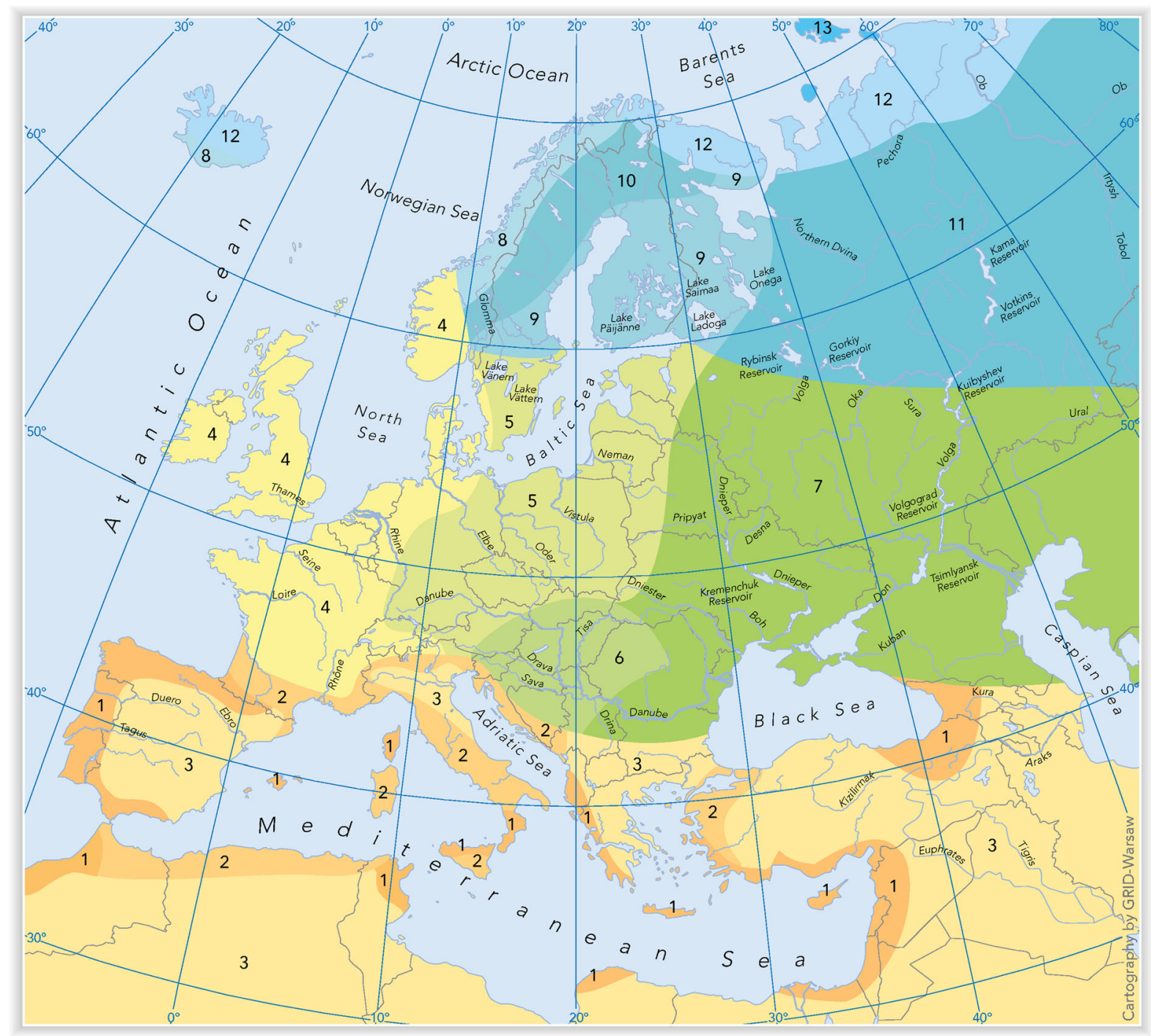

\begin{tabular}{|c|c|c|c|}
\hline \multicolumn{4}{|c|}{ Climate } \\
\hline \multirow{2}{*}{\multicolumn{2}{|c|}{ Subtropical climates: }} & \multicolumn{2}{|l|}{$500 \mathrm{~km}$} \\
\hline & & \multicolumn{2}{|c|}{ group of cold climates: } \\
\hline 1 & maritime & 8 & maritime \\
\hline 2 & intermediate & 9 & transitional \\
\hline 3 & continental & 10 & intermediate \\
\hline \multicolumn{2}{|c|}{$\begin{array}{l}\text { Temperate climates: } \\
\text { group of warm climates }\end{array}$} & 11 & continental \\
\hline 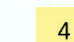 & maritime & \multicolumn{2}{|c|}{ Circumpolar climates: } \\
\hline 5 & transitional & 12 & subpolar \\
\hline 6 & intermediate & 13 & polar \\
\hline 7 & continental & 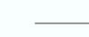 & country borders \\
\hline
\end{tabular}


Table 1 Herb species and the main types of natural compounds investigated during seasons in references ${ }^{\mathrm{a}}$

\begin{tabular}{|c|c|c|c|c|c|c|}
\hline $\begin{array}{l}\text { Climate } \\
\text { classification }\end{array}$ & Countries & Families & Species & $\begin{array}{l}\text { Types of natural } \\
\text { products }\end{array}$ & $\begin{array}{l}\text { Research } \\
\text { organs }\end{array}$ & References \\
\hline \multirow[t]{21}{*}{ Mediterranean $^{\mathrm{b}}$} & Spain & Asteraceae & Artemisia absinthium L. & Essential oil & Aerial parts & $\begin{array}{l}\text { Llorens-Molina } \\
\text { and Vacas } \\
\text { (2015) }\end{array}$ \\
\hline & Greece & Asteraceae & $\begin{array}{l}\text { Artemisia arborescens } \\
\text { (Vaill.) L. }\end{array}$ & Essential oil & Aerial parts & $\begin{array}{l}\text { Michelakis } \\
\text { et al. (2016) }\end{array}$ \\
\hline & France & Asteraceae & $\begin{array}{l}\text { Calendula arvensis } \\
\text { M.Bieb. }^{\text {c }}\end{array}$ & Essential oil & Aerial parts & $\begin{array}{l}\text { Paolini et al. } \\
\text { (2010) }\end{array}$ \\
\hline & Italy & Lamiaceae & $\begin{array}{l}\text { Clinopodium nepeta (L.) } \\
\text { Kuntze }\end{array}$ & $\begin{array}{l}\text { Phenolic acids, } \\
\text { Flavonoids }\end{array}$ & Leaves & $\begin{array}{l}\text { Pacifico et al. } \\
\text { (2015) }\end{array}$ \\
\hline & Italy & Apiaceae & Foeniculum vulgare Mill. & $\begin{array}{l}\text { Phenylpropanoids, } \\
\text { Flavonoids }\end{array}$ & Leaves & $\begin{array}{l}\text { Scognamiglio } \\
\text { et al. (2015) }\end{array}$ \\
\hline & & Asteraceae & $\begin{array}{l}\text { Helichrysum italicum } \\
\text { (Roth) G.Don }\end{array}$ & & & \\
\hline & & Lamiaceae & $\begin{array}{l}\text { Micromeria graeca (L.) } \\
\text { Benth. ex Rchb. }\end{array}$ & & & \\
\hline & & Lamiaceae & $\begin{array}{l}\text { Clinopodium nepeta }(\mathrm{L} .) \\
\text { Kuntze }\end{array}$ & & & \\
\hline & & Lamiaceae & Origanum vulgare $\mathrm{L}$. & & & \\
\hline & & Lamiaceae & Satureja montana L. & & & \\
\hline & & Lamiaceae & $\begin{array}{l}\text { Thymus longicaulis } \\
\text { C.Presl }\end{array}$ & & & \\
\hline & $\begin{array}{l}\text { Bosnia and } \\
\text { Herzegovina }\end{array}$ & Asteraceae & $\begin{array}{l}\text { Helichrysum italicum } \\
\text { (Roth) G.Don }\end{array}$ & Essential oil & Aerial parts & $\begin{array}{l}\text { Talić et al. } \\
\text { (2019) }\end{array}$ \\
\hline & Italy & Hypericaceae & $\begin{array}{l}\text { Hypericum perforatum } \mathrm{L} \text {. } \\
\text { subsp. }\end{array}$ & $\begin{array}{l}\text { Hypericins, } \\
\text { Hyperforins, } \\
\text { Flavonoids }\end{array}$ & Aerial parts & $\begin{array}{l}\text { Filippini et al. } \\
\text { (2010) }\end{array}$ \\
\hline & & & perforatum & & & \\
\hline & & & $\begin{array}{l}\text { angustifolium (DC.) } \\
\text { Gaudin }\end{array}$ & & & \\
\hline & & & $\begin{array}{l}\text { veronense (Schrank) } \\
\text { Frolich }\end{array}$ & & & \\
\hline & France & Hypericaceae & Hypericum perforatum $\mathrm{L}$. & Essential oil & Aerial parts & $\begin{array}{l}\text { Schwob et al. } \\
\text { (2004) }\end{array}$ \\
\hline & Croatia & Lamiaceae & $\begin{array}{l}\text { Origanum vulgare L. } \\
\text { subsp. hirtum (Link) } \\
\text { Ietsw. }\end{array}$ & Essential oil & Aerial parts & $\begin{array}{l}\text { Jerković et al. } \\
\text { (2001b) }\end{array}$ \\
\hline & Croatia & Lamiaceae & $\begin{array}{l}\text { Origanum vulgare L. } \\
\text { subsp. hirtum (Link) } \\
\text { Ietsw. }\end{array}$ & Essential oil & Aerial parts & $\begin{array}{l}\text { Jerković et al. } \\
\text { (2001a) }\end{array}$ \\
\hline & Italy & Rutaceae & Ruta graveolens L. & Phenolics & Leaves & $\begin{array}{l}\text { Pacifico et al. } \\
\text { (2016) }\end{array}$ \\
\hline & Croatia & Lamiaceae & $\begin{array}{l}\text { Satureja montana L., } \\
\text { Satureja cuneifolia Ten. }\end{array}$ & Essential oil & Aerial parts & $\begin{array}{l}\text { Milos et al. } \\
\text { (2001) }\end{array}$ \\
\hline
\end{tabular}


Table 1 continued

\begin{tabular}{|c|c|c|c|c|c|c|}
\hline $\begin{array}{l}\text { Climate } \\
\text { classification }\end{array}$ & Countries & Families & Species & $\begin{array}{l}\text { Types of natural } \\
\text { products }\end{array}$ & $\begin{array}{l}\text { Research } \\
\text { organs }\end{array}$ & References \\
\hline & Spain & Scrophulariaceae & $\begin{array}{l}\text { Scrophularia scorodonia } \\
\text { L. }\end{array}$ & Harpagoside & $\begin{array}{l}\text { Leaves, } \\
\text { Flowers, } \\
\text { Steams }\end{array}$ & $\begin{array}{l}\text { Galíndez et al. } \\
\text { (2000) }\end{array}$ \\
\hline & Greece & Lamiaceae & Thymbra spicata $\mathrm{L}$. & Essential oil & Leaves, Flowers & $\begin{array}{l}\text { Stefanaki et al. } \\
\text { (2018) }\end{array}$ \\
\hline & Italy & Lamiaceae & $\begin{array}{l}\text { Thymus longicaulis } \\
\text { C.Presl }\end{array}$ & $\begin{array}{l}\text { Phenolic acids, } \\
\text { Flavonoids }\end{array}$ & Leaves & $\begin{array}{l}\text { Galasso et al. } \\
\text { (2014) }\end{array}$ \\
\hline \multirow[t]{17}{*}{ Temperate } & Germany & Rosaceae & Alchemilla vulgaris $\mathrm{L}$. & $\begin{array}{l}\text { Ellagitannins, } \\
\text { Flavonoids }\end{array}$ & Leaves, Stalks & $\begin{array}{l}\text { Duckstein et al. } \\
\text { (2012) }\end{array}$ \\
\hline & & & $\begin{array}{l}\text { Alchemilla mollis (Buser) } \\
\text { Rothm. }\end{array}$ & & & \\
\hline & Denmark & Plantaginaceae & Antirrhinum majus L. & Iridoids & Aerial parts & $\begin{array}{l}\text { Drøhse } \\
\text { Høgedal and } \\
\text { Mølgaard } \\
(2000)\end{array}$ \\
\hline & $\begin{array}{l}\text { The } \\
\text { Netherlands }\end{array}$ & Asteraceae & Artemisia аппиа $\mathrm{L}^{3}$ & Artemisinin & Leaves & $\begin{array}{l}\text { Wallaart et al. } \\
\text { (2000) }\end{array}$ \\
\hline & Denmark & Brassicaceae & Barbarea vulgaris R.Br. & Glucosinolates & Leaves & $\begin{array}{l}\text { Agerbirk et al. } \\
\text { (2001) }\end{array}$ \\
\hline & Serbia & Lamiaceae & $\begin{array}{l}\text { Clinopodium pulegium } \\
\text { (Rochel) Bräuchler }\end{array}$ & Essential oil & Aerial parts & $\begin{array}{l}\text { Slavkovska } \\
\text { et al. (2013) }\end{array}$ \\
\hline & Denmark & Asteraceae & $\begin{array}{l}\text { Echinacea purpurea (L.) } \\
\text { Moench, Echinacea } \\
\text { pallida (Nutt.) Nutt. }\end{array}$ & $\begin{array}{l}\text { Lipophilic } \\
\text { compounds, } \\
\text { Phenolic acids }\end{array}$ & Roots & $\begin{array}{l}\text { Thomsen et al. } \\
\text { (2012) }\end{array}$ \\
\hline & Serbia & Gentianaceae & Gentiana lutea L. & $\begin{array}{l}\text { Iridoids, } \\
\text { Flavonoids }\end{array}$ & Leaves, Flowers & $\begin{array}{l}\text { Menković et al. } \\
\text { (2000) }\end{array}$ \\
\hline & Hungary & Lamiaceae & Glechoma hederacea L. & Phenolics & Aerial parts & $\begin{array}{l}\text { Varga et al. } \\
\text { (2016) }\end{array}$ \\
\hline & $\begin{array}{l}\text { Czech } \\
\text { Republic }\end{array}$ & Fabaceae & Glycyrrhiza glabra L. & Phenolics & Roots & $\begin{array}{l}\text { Cheel et al. } \\
\text { (2013) }\end{array}$ \\
\hline & Slovakia & Hypericaceae & $\begin{array}{l}\text { Hypericum maculatum } \\
\text { Crantz }\end{array}$ & $\begin{array}{l}\text { Hypericins, } \\
\text { Flavonoids }\end{array}$ & Flower organs & $\begin{array}{l}\text { Mártonfi et al. } \\
\text { (2006) }\end{array}$ \\
\hline & Slovakia & Hypericaceae & $\begin{array}{l}\text { Hypericum perforatum } \\
\text { subsp. veronense } \\
\text { (Schrank) H.Lindb }\end{array}$ & $\begin{array}{c}\text { Dianthrones, } \\
\text { hyperforin, } \\
\text { flavonoids }\end{array}$ & Flowers & $\begin{array}{l}\text { Tekel'ová et al. } \\
\text { (2000) }\end{array}$ \\
\hline & $\begin{array}{l}\text { Czech } \\
\text { Republic }\end{array}$ & Papaveraceae & $\begin{array}{l}\text { Macleaya microcarpa } \\
\text { (Maxim.) Fedde }\end{array}$ & Alkaloids & $\begin{array}{l}\text { Aerial parts, } \\
\text { Underground } \\
\text { parts }\end{array}$ & $\begin{array}{l}\text { Pěnčíková et al. } \\
\text { (2011) }\end{array}$ \\
\hline & Poland & Fabaceae & Medicago sativa $\mathrm{L}$. & Flavonoids & Aerial parts & $\begin{array}{l}\text { Stochmal and } \\
\text { Oleszek } \\
(2007)\end{array}$ \\
\hline & Poland & Lamiaceae & $\begin{array}{l}\text { Melittis melissophyllum } \\
\text { L. }\end{array}$ & Phenolic acids & Aerial parts & $\begin{array}{l}\text { Skrzypczak- } \\
\text { Pietraszek } \\
\text { and } \\
\text { Pietraszek } \\
\text { (2012) }\end{array}$ \\
\hline & Poland & Lamiaceae & $\begin{array}{l}\text { Melittis melissophyllum } \\
\text { L. }\end{array}$ & Flavonoids & Leaves, Flowers & $\begin{array}{l}\text { Skrzypczak- } \\
\text { Pietraszek } \\
\text { and } \\
\text { Pietraszek } \\
\text { (2014) }\end{array}$ \\
\hline & Slovakia & Lamiaceae & Mentha $\times$ piperita $\mathrm{L}$. & Essential oil & Not clear & $\begin{array}{l}\text { Grulova et al. } \\
\text { (2015) }\end{array}$ \\
\hline
\end{tabular}


Table 1 continued

\begin{tabular}{|c|c|c|c|c|c|c|}
\hline $\begin{array}{l}\text { Climate } \\
\text { classification }\end{array}$ & Countries & Families & Species & $\begin{array}{l}\text { Types of natural } \\
\text { products }\end{array}$ & $\begin{array}{l}\text { Research } \\
\text { organs }\end{array}$ & References \\
\hline & $\begin{array}{l}\text { The } \\
\text { Netherlands }\end{array}$ & Amaryllidaceae & $\begin{array}{l}\text { Narcissus } \\
\text { pseudonarcissus L. cv. } \\
\text { Carlton }\end{array}$ & Alkaloids & $\begin{array}{l}\text { Bulbs, Leaves, } \\
\text { Roots }\end{array}$ & $\begin{array}{l}\text { Lubbe et al. } \\
\text { (2013) }\end{array}$ \\
\hline & Poland & Boraginaceae & Pulmonaria officinalis $\mathrm{L}$. & $\begin{array}{l}\text { Phenolic acids, } \\
\text { Flavonoids }\end{array}$ & Aerial parts & $\begin{array}{c}\text { Krzyżanowska- } \\
\text { Kowalczyk } \\
\text { et al. (2018) }\end{array}$ \\
\hline & Serbia $^{d}$ & Lamiaceae & Satureja horvatii Šilić & Essential oil & Aerial parts & $\begin{array}{l}\text { Lakušić et al. } \\
\text { (2011) }\end{array}$ \\
\hline & $\begin{array}{l}\text { Czech } \\
\text { Republic }\end{array}$ & Papaveraceae & $\begin{array}{l}\text { Stylophorum lasiocarpum } \\
\text { (Oliv.) Fedde }\end{array}$ & Alkaloids & $\begin{array}{l}\text { Aerial parts, } \\
\text { Roots }\end{array}$ & $\begin{array}{l}\text { Šebrlová et al. } \\
\text { (2015) }\end{array}$ \\
\hline & Lithuania & Lamiaceae & Thymus L. species & $\begin{array}{l}\text { Phenolic acids, } \\
\text { Flavonoids, } \\
\text { Triterpenic acids }\end{array}$ & Aerial parts & $\begin{array}{l}\text { Raudone et al. } \\
\text { (2017) }\end{array}$ \\
\hline & & & $\begin{array}{l}\text { T. austriacus Bernh. ex } \\
\text { Rchb. }\end{array}$ & & & \\
\hline & & & $\begin{array}{l}\text { T. } \times \text { citriodorus } \\
\text { Schweig. et Korte }\end{array}$ & & & \\
\hline & & & T. longicaulis C.Presl & & & \\
\hline & & & T. $\times$ oblongifolius Opiz & & & \\
\hline & & & $\begin{array}{l}\text { T. praecox Opiz } \\
\text { subsp. arcticus } \\
\text { (Durand) Jalas }\end{array}$ & & & \\
\hline & & & T. pulegioides L. & & & \\
\hline & & & T. sibthorpii Benth. & & & \\
\hline & & & T. serpyllum $\mathrm{L}$. & & & \\
\hline \multirow[t]{2}{*}{ Cold } & Russia & Papaveraceae & $\begin{array}{l}\text { Corydalis bracteata } \\
\text { (Steph. ex Willd.) Pers. }\end{array}$ & Alkaloids & Whole plants & $\begin{array}{l}\text { Khodorova } \\
\text { et al. (2013) }\end{array}$ \\
\hline & Finland & Geraniaceae & Geranium sylvaticum $\mathrm{L}$. & $\begin{array}{l}\text { Tannins, } \\
\text { Flavonoids, } \\
\text { Phenolic acids }\end{array}$ & $\begin{array}{l}\text { Leaves, Roots, } \\
\text { Steams, } \\
\text { Flower organs }\end{array}$ & $\begin{array}{l}\text { Tuominen and } \\
\text { Salminen } \\
\text { (2017) }\end{array}$ \\
\hline
\end{tabular}

${ }^{a}$ All the binomial names were checked and revised according to World Flora Online (http://www.worldfloraonline.org/), in a few some cases original names used in the papers were kept (indicated in the text)

${ }^{\mathrm{b}}$ Climate classification was based on the climate map from the European Environment Agency (Fig. 1)

${ }^{\mathrm{c}}$ Annual herbs, others are perennial herbs

${ }^{\mathrm{d}}$ Samples collected in mostly Serbia (Temperate climate area) and Montenegro (Mediterranean climate area)

different ecologically relevant and interlinked variables (Zidorn 2018). Though often studied in various countries and climate zones, seasonal changes of natural products in herbs in Europe, from the Mediterranean to cold climates, have not been systematically reviewed yet.

\section{Mediterranean climate}

As shown in Figs. 1 and 2, large parts of several countries, e.g., Croatia, Greece, Italy, and Spain, located around the Mediterranean Basin and in the West of the Iberian Peninsula have a typical Mediterranean climate. Literature data are reviewed in alphabetical order of taxon names; the respective family names are indicated in brackets.

Llorens-Molina and Vacas (2015) studied seasonal variations in the essential oil of aerial parts and roots of Artemisia absinthium L. (Asteraceae) growing in Teruel, Spain. Five individual plants were randomly selected during the entire growing cycle from May 2012 to January 2013. The essential oil yield from aerial parts reached a low, both in spring and winter 
Table 2 Shrub/subshrub species and the main types of natural compounds investigated during seasons in references ${ }^{\mathrm{a}}$

\begin{tabular}{|c|c|c|c|c|c|c|c|}
\hline $\begin{array}{l}\text { Climate } \\
\text { classification }\end{array}$ & Countries & Families & Species & Life forms & $\begin{array}{l}\text { Types of } \\
\text { natural } \\
\text { products }\end{array}$ & $\begin{array}{l}\text { Organs } \\
\text { References }\end{array}$ & References \\
\hline \multirow[t]{10}{*}{ Mediterranean $^{\mathrm{b}}$} & Spain & Plantaginaceae & $\begin{array}{l}\text { Digitalis obscura } \\
\quad \text { L. }\end{array}$ & Subshrub & Cardenolide & Leaves & $\begin{array}{l}\text { Roca-Pérez et al. } \\
\text { (2004) }\end{array}$ \\
\hline & Portugal & Hypericaceae & $\begin{array}{l}\text { Hypericum } \\
\text { androsaemum L. }\end{array}$ & Shrub & Essential oil & Aerial parts & $\begin{array}{l}\text { Guedes et al. } \\
(2004)\end{array}$ \\
\hline & Italy & Lamiaceae & $\begin{array}{l}\text { Rosmarinus } \\
\text { officinalis L. }\end{array}$ & Shrub & Essential oil & Aerial parts & $\begin{array}{l}\text { Melito et al. } \\
\text { (2019) }\end{array}$ \\
\hline & Italy & Lamiaceae & $\begin{array}{l}\text { Rosmarinus } \\
\text { officinalis L. }\end{array}$ & Shrub & Essential oil & Aerial parts & $\begin{array}{l}\text { Serralutzu et al. } \\
\quad(2020)\end{array}$ \\
\hline & Spain & Lamiaceae & $\begin{array}{l}\text { Rosmarinus } \\
\text { officinalis L. }\end{array}$ & Shrub & Essential oil & Aerial parts & $\begin{array}{l}\text { Salido et al. } \\
\text { (2003) }\end{array}$ \\
\hline & Greece & Lamiaceae & $\begin{array}{l}\text { Rosmarinus } \\
\text { officinalis } \\
\text { L., Salvia } \\
\text { fruticosa Mill. }\end{array}$ & $\begin{array}{l}\text { Shrub } \\
\text { Subshrub }\end{array}$ & $\begin{array}{l}\text { Essential oil, } \\
\text { Flavonoids, } \\
\text { Phenolic } \\
\text { acids }\end{array}$ & Aerial parts & $\begin{array}{l}\text { Papageorgiou } \\
\text { et al. (2008a) }\end{array}$ \\
\hline & Croatia & Lamiaceae & Salvia officinalis L. & Subshrub & $\begin{array}{l}\text { Flavonoids, } \\
\text { Phenolic } \\
\text { acids }\end{array}$ & Leaves & $\begin{array}{l}\text { Generalić et al. } \\
\text { (2012) }\end{array}$ \\
\hline & Portugal & Lamiaceae & Salvia officinalis L. & Subshrub & Essential oil & Aerial parts & $\begin{array}{l}\text { Santos-Gomes } \\
\text { and } \\
\text { Fernandes- } \\
\text { Ferreira (2001) }\end{array}$ \\
\hline & Spain & Lamiaceae & $\begin{array}{l}\text { Salvia officinalis } \\
\text { subsp. } \\
\text { lavandulifolia } \\
\text { (Vahl) Gams }\end{array}$ & Subshrub & Essential oil & Aerial parts & $\begin{array}{c}\text { Usano-Alemany } \\
\text { et al. (2012) }\end{array}$ \\
\hline & Italy & Lamiaceae & Thymus vulgaris L. & Subshrub & Terpenoids & Aerial parts & $\begin{array}{l}\text { Hudaib et al. } \\
\text { (2002) }\end{array}$ \\
\hline \multirow[t]{4}{*}{ Temperate } & Serbia & Lamiaceae & $\begin{array}{l}\text { Rosmarinus } \\
\text { officinalis L. }\end{array}$ & Shrub & Essential oil & Aerial parts & $\begin{array}{l}\text { Lakušić et al. } \\
\text { (2013a) }\end{array}$ \\
\hline & UK & Lamiaceae & $\begin{array}{l}\text { Rosmarinus } \\
\text { officinalis L. }\end{array}$ & Shrub & Phenolic acids & $\begin{array}{l}\text { Petals, } \\
\text { Sepals, } \\
\text { Leaves, } \\
\text { Stems, } \\
\text { Roots }\end{array}$ & $\begin{array}{l}\text { Luis and } \\
\text { Johnson } \\
(2005)\end{array}$ \\
\hline & Serbia & Lamiaceae & Salvia officinalis L. & Subshrub & Essential oil & Leaves & $\begin{array}{l}\text { Lakušić et al. } \\
\text { (2013b) }\end{array}$ \\
\hline & Austria & Lamiaceae & Salvia officinalis L. & Subshrub & Essential oil & Leaves & $\begin{array}{l}\text { Grausgruber- } \\
\text { Gröger et al. } \\
\text { (2012) }\end{array}$ \\
\hline
\end{tabular}

a,b The same as Table 1

samples. The highest levels were detected during the peak of the flowering season; levels decreased towards the end of the flowering season, increased again, and afterwards significantly decreased throughout winter. In the investigated population, two distinct chemotypes (A and B) occurred. Chemotype A was characterized by the prevalence of ( $Z$ )-epoxyocimene; chemotype B contained similar quantities of (Z)epoxyocimene and $(Z)$-chrysanthemyl acetate. In both chemotypes, (Z)-epoxyocimene showed similar trends, which increased during the vegetative development (stronger for chemotype B) and displayed 


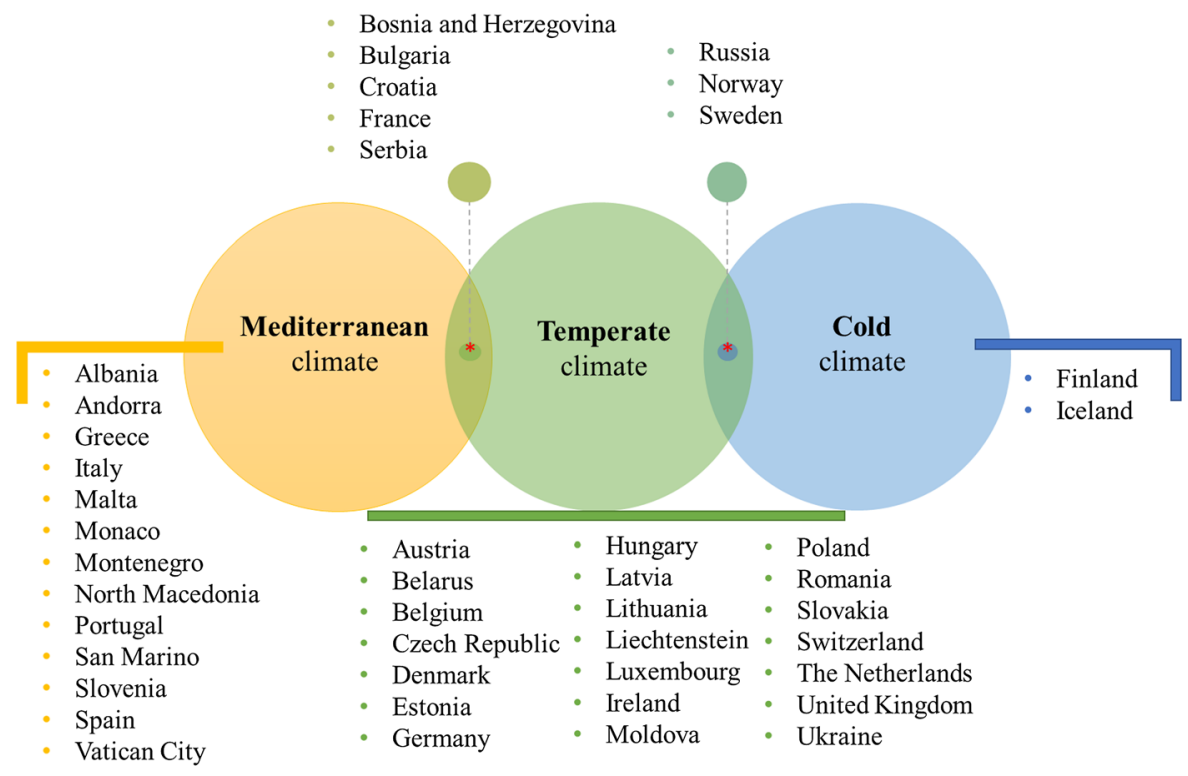

Fig. 2 Assignment of European countries to the three main climate zones of Europe. *Mixture of climates of Mediterranean/temperate or temperate/cold

lower concentration after the end of the flowering period. However, $(Z)$-chrysanthemyl acetate exhibited an opposite variation during the vegetative growth, followed by an increase at the end of flowering. Relative linalool contents reached a peak at the end of flowering for chemotypes A and B. Essential oil composition did not differ in roots regardless of chemotype. Bornyl acetate in roots displayed a significant seasonal difference; the amount increased from spring and levels were stable until a final peak in winter. Likewise, neryl isovalerate exhibited the highest levels during the phase of vegetative growing. Some minor oxygenated monoterpenes showed a steady increase over the developmental stages.

Michelakis et al. (2016) studied seasonal variation and distillation conditions of essential oils from Artemisia arborescens (Vaill.) L. (Asteraceae) growing in Greece. Plants were sampled in the stages of dormancy, early flowering, and full flowering in December, April, and May respectively. In total, 47 natural products were identified, three of those were main components. The prevalent component, chamazulene ranged from $26.5 \%$ in December to $51.1 \%$ in May; camphor showed the same pattern, which increased from $18.9 \%$ to $32.2 \%$, while $\beta$ thujone was present with an increase from December (8.3\%) to April (14.8\%), and a decrease in May $(6.4 \%)$. At the most efficient $\mathrm{pH}$ value of 8.3 , the chamazulene amount increased 1.3-fold compared to distillation under neutral conditions, reaching $65.1 \%$ of the total content of the essential oil.

Paolini et al. (2010) studied seasonal variation in essential oils of Calendula arvensis L. (Asteraceae) growing in Corsica, France. Eight specimens of the aerial parts of plant were collected at the flowering stage during winter and spring. Results showed that $\alpha$ cadinol concentration was in inverse proportion to the concentration of $\delta$-cadinene (the corresponding hydrocarbon). The oils obtained from the February samples showed lower levels of $\alpha$-cadinol ( $\alpha$-cadinol $/ \delta$ cadinene ratio close to $1: 1)$ than those obtained from May samples (ratio of up to 3:1). Furthermore, statistical analysis clustered the samples from 25 localities of Corsica into two distinct groups, which can distinguish samples from northeast Corsica or the West and the South of Corsica.

Pacifico et al. (2015) investigated seasonal variation in phenolic composition, antioxidant and antiinflammatory activities of Clinopodium nepeta (L.) Kuntze (Lamiaceae) growing in Durazzano, Campania, Italy. Specimens of the taxon were collected at different vegetative stages in July and October of 2012 and January and April of 2013. Acacetin derivatives were the dominant compounds and showed the highest levels in April. Quercetin glycosides were mainly accumulated during summer and autumn. In 
particular, the content of quercetin 3-O-(6"-3-hydroxy-3-methyl-glutaroyl) hexoside in the October sample was 4.12, 68.1 and 11.6-fold higher than in samples from July, January, and April, respectively. Caffeic acid tetrameric and pentameric derivatives, as well as acacetin and its glycosides, showed parallel seasonal trends. Levels of these natural products in the investigated samples were in the following order April $>$ January $>$ July $>$ October. Samples collected in summer had the strongest antioxidant capability in cell-free systems. In contrast, cyto-protective and anti-inflammatory activities were most pronounced in samples collected in winter.

Scognamiglio et al. (2015) studied the primary and secondary metabolites in seven aromatic Mediterranean plant species from the Apiaceae, Asteraceae, and Lamiaceae families growing in Italy. Plants were sampled at different seasons and analyzed by NMR. Compounds were identified based on a comparison of NMR data with literature values and were confirmed by $2 \mathrm{D}$ NMR analyses. Signal areas in ${ }^{1} \mathrm{H}$ NMR spectra corresponding to an internal standard were used to calculate the relative amounts of the compounds. The analysis of NMR spectra revealed that for all investigated Lamiaceae species, the content of aromatic compounds in spring and summer samples was higher than in samples collected in autumn and winter. Foeniculum vulgare Mill. (Apiaceae) and Helichrysum italicum (Roth) G.Don (Asteraceae) extracts showed analogous trends, too.

The oil composition of Helichrysum italicum collected in Bosnia-Herzegovina was investigated using GC/MS by Talić et al. (2019). Specimens were collected in February, May, June, August, and October 2016. The dominant constituents in May and August were monoterpenes. The prominent compounds were $\beta$-diketones, displaying the highest relative content (31.9\%) in winter, followed by a decrease during the growing cycle until the lowest relative content $(11.0 \%)$ in mid-autumn. An increase in $\beta$-diketones coincided with a decrease in sesquiterpenes.

Filippini et al. (2010) evaluated variations of natural products from three different subspecies of Hypericum perforatum L. (Hypericaceae) growing in Italy during three developmental stages. Samples were collected at floral budding, full flowering, and early fruiting stages. The naphtodiantrone hypericin reached the maximum in subspecies angustifolium (DC.) Gaudin and perforatum during full flowering, while in subspecies veronense (Schrank) Frohlich the highest level was observed before the flowering stage. The most abundant lipophilic compound in $H$. perforatum, hyperforin, showed diverging patterns between subspecies. In $H$. perforatum subsp. perforatum, the highest level was reached at the flowering stage; in contrast, in both subspecies angustifolium and subspecies veronense, the highest level was detected after the flowering stage. All three subspecies produced hyperoside, and the content of this natural product significantly decreased during ontogenesis. Although the qualitative profiles of individual flavonoids of the three subspecies were different, the total flavonoid contents showed no significant differences with maxima before and during the flowering stage.

Schwob et al. (2004) studied changes in essential oil composition of Hypericum perforatum (Hypericaceae) growing in South-Eastern France. Aerial parts of 30 wild individuals were collected for each development stage using a randomized collection scheme. The essential oil yield ranged from 0.06 to $0.09 \%$; the yield reached the minimum during fruiting and increased from 0.07 to $0.09 \%$ during flowering. Regarding the different groups of compounds, the proportion of monoterpenoids was low $(0.7-0.8 \%$ corresponding to $0.05-0.06 \mu \mathrm{g} / \mathrm{g}$ ) before anthesis. During flowering, it was at $4.2 \%(0.39 \mu \mathrm{g} / \mathrm{g})$ and reached $9.5 \%(0.56 \mu \mathrm{g} / \mathrm{g})$ at the fruiting stage. Sesquiterpenoids contributed 53\%, 75\%, 68\%, and $58 \%$ (corresponding to $3.73,6.24,6.23,2.38 \mu \mathrm{g} / \mathrm{g}$ ) to the composition of the oils of $H$. perforatum at the vegetative, floral budding, flowering, and fruiting stages, respectively. Aliphatic alcohols contributed $13.7 \%$ at the vegetative stage and then decreased to $6.3 \%$ at the fruiting stage.

Jerković et al. (2001b) studied the impact of both seasonal variations and drying on the volatile constituents of Origanum vulgare L. subsp. hirtum (Link) Ietsw. (Lamiaceae) from the South of Croatia. Five seasonal samples were collected between April to August. The authors found the highest content of $p$ cymene in August. A higher percentage of thymol was associated with a lower carvacrol content (and vice versa) in all samples; this was interpreted by the authors as a potential connection between the biosynthetic pathways of these dominant compounds. Drying at room temperature did not affect the qualitative composition of oregano oil, but led to a minor decrease in essential oil yield compared with fresh oregano and 
this trend was also observed for the glycosidically bound volatiles of oregano (Jerković et al. 2001a).

Pacifico et al. (2016) studied chemical composition in hydroalcoholic extracts of leaves of Ruta graveolens L. (Rutaceae) growing in the wild in Southern Italy. Plants were harvested on the tenth day of July and October 2012 and of January and April 2013. Each of these days was in the first month of a new (meteorological) season. Results were complex, but in general, total phenolics contents showed a maximum in spring. Spring samples also displayed the best antioxidant activity in cell-free test assays.

Seasonal variations of the chemical composition of essential oils of Satureja cuneifolia Ten. and $S$. montana L. (Lamiaceae) growing in three locations in Croatia were analyzed by Milos et al. (2001). Aerial parts of plants were sampled at the following stages, before flowering (July), during flowering (September), and after flowering (November). In essential oils of $S$. montana, the oxygen-containing phenolic monoterpenes carvacrol (16.1-52.4\%) and thymol (1.9$20.6 \%$ ) were found to be the major constituents. Carvacrol showed different seasonal patterns between the different sampling sites. Thymol showed the highest amount in July (prior to flowering). Concentrations of $p$-cymene and borneol increased steadily during the developmental stages. In S. cuneifolia, all samples contained a low percentage of thymol and carvacrol, but samples were relatively rich in $\gamma$ terpinene, $p$-cymene, $\alpha$-pinene, and limonene. There was no discernible seasonality of the major essential oil constituents of $S$. cuneifolia. Additionally, no clear correlations between oil yield or composition and locality or environmental conditions were found in either S. montana or S. cuneifolia.

Galíndez et al. (2000) quantified harpagoside contents in different organs of Scrophularia scorodonia L. (Scrophulariaceae) harvested in Jaén, Spain. Leaves, stems, and flowers of plants were collected monthly in the year 1995. The contents of harpagoside in the extracts from leaves were highest $(1.90 \%)$ in July followed by a decrease from September to December. However, the amount of harpagoside increased steadily from January to July (1.15$1.90 \%$ ). Additionally, harpagoside was found in each monthly sample of stems; the highest amount of total harpagoside occurred in July $(0.65 \%)$. In flower samples, the quantity of harpagoside was usually low, but in April, a substantially higher level of this compound was observed $(0.63 \%)$.

Stefanaki et al. (2018) compared the composition of the essential oil of Thymbra spicata L. (Lamiaceae) between two seasons (spring and summer). The aerial parts of the taxon were harvested from 20 locations on Chios Island in Greece, ten in May and ten in July. The yield was observed to be significantly higher in May at the beginning of flowering compared to the full flowering period in July. Only the content of caryophyllene oxide showed the same pattern as the oil yield. In contrast, the other main compounds i.e., carvacrol, $p$-cymene, and $\gamma$-terpinene showed no significant differences between the investigated months. Moreover, the authors found that the composition of $p$-cymene, $\gamma$-terpinene, and some other minor compounds were correlated with the geographical variation of Th. spicata.

Galasso et al. (2014) quantified changes in the chemical composition of extracts of Thymus longicaulis C. Presl (Lamiaceae) growing in Italy, and their antioxidant and anti-inflammatory properties. Three replicate samples of leaves were collected in July and October 2012 and in January and April of 2013. Each sample was phytochemically analyzed by LC-DADESI-MS/MS. The content of rosmarinic acid and its derivatives was negatively correlated with the content of the luteolin pentosyl derivatives. Rosmarinic acid was remarkably abundant in the October sample and reached the lowest value in July. The highest antioxidant and anti-inflammatory activity were present in the October extract, which possessed high amounts of rosmarinic acid and methylapigenin.

\section{Temperate climate}

Temperate climates are the main climate type in Europe (Fig. 1-2). Middle, Eastern as well as Western Europe are generally characterized by a temperate climate, for instance, Austria, Czech Republic, France, Germany, the Netherlands, and the UK.

Duckstein et al. (2012) compared phenolic components from Alchemilla vulgaris L. and Alchemilla mollis (Buser) Rothm. (Rosaceae) growing in Germany. Leaves and stalks of Alchemilla were harvested in May (start of the flowering period) and August 2010 (end of the flowering period). In both species, agrimoniin (a dimeric hydrolysable tannin), one of 
the main components, was present by more than $100 \%$ higher in May than in August. The same trend was also observed for other ellagitannins and also the major flavonoid, a quercetin glucuronide, increased nearly by $30 \%$.

Drøhse Høgedal and Mølgaard (2000) studied seasonal and diurnal variations in the contents of iridoids in cultivars of Antirrhinum majus L. (Plantaginaceae) grown in Denmark. Plants were harvested weekly between June 17 and September 30, and twice a week during the flowering period. Total iridoid contents revealed an accumulation, with high contents (around $100 \mathrm{mg} / \mathrm{g}$ dry matter), early and late in the season. All iridoids showed very low contents in August when plants were at the onset of flowering. The relative percentage of antirrhinoside was substantially higher before flowering than after bud break. The relative decrease in antirrhinoside was occurring in parallel with an increase of antirrhide, which occurred in significantly higher concentrations after the onset of flowering. The diurnal variation ranged from 20 to $60 \mathrm{mg} / \mathrm{g}$. In contrast, no correlations related to light/darkness conditions, temperature patterns or water content were observed.

Wallaart et al. (2000) studied the levels of artemisinin, its biosynthetic precursors, and biosynthetically related sesquiterpenes during phenological stages in Artemisia annua L. (Asteraceae) of different origins. Seeds of A. annua originating from China, Germany, the USA, Vietnam, and Yugoslavia were obtained and then cultivated in an experimental field in the Netherlands. Leaves of each plant were sampled weekly at the middle of the day from July to November. A chemotype exhibiting high contents of artemisinin and dihydroartemisinic acid and low contents of artemisinic acid was represented by the Vietnamese A. аппиа accession. Other chemotypes presenting relatively low contents of artemisinin and dihydroartemisinic acid, but high artemisinic acid were represented by the Chinese, European, and American A. annua accessions. Specimens from Vietnam seemed to be the most suitable chemotype for the commercial production of artemisinin. In November, the artemisinin content of the Vietnamese A. апnиa had considerably increased by almost $58 \%$, after a period of moderate decline. In parallel, the content of dihydroartemisinic acid had decreased by $39 \%$ and thus to a content lower than that of artemisinin. The authors found these radical changes in the natural products levels were coinciding with the onset of night frost.

Agerbirk et al. (2001) studied two different types of Barbarea vulgaris R.Br. (Brassicaceae) for seasonal changes in the contents of glucosinolates and the resistance of the plants of both types to the crucifer specialist flea beetle Phyllotreta nemorum Linnaeus. Leaves of B. vulgaris subsp. arcuata (Opiz) Hayek were harvested at seven natural growing locations in Denmark from August to November, once per month. The contents of all dominant glucosinolates in the plants showed an increase from August to November at five localities. In the remaining two localities, glucosinolates accumulated from September to November. Additionally, no correlation between glucosinolate contents and insect resistance was detected. Glucosinolate levels also did not correlate with the variation in resistance between the P-type (always susceptible) and the G-type (resistant in the summer season).

The variability of essential oil compositions of Clinopodium pulegium (Rochel) Bräuchler from its natural habitat and from cultivated plants was investigated by Slavkovska et al. (2013). Plants were harvested from the Svrljiški Timok gorge, Serbia (wild) and Niš, Serbia (cultivated) during different vegetative phases. The plants growing in the natural habitat yielded the lowest content of oil with $1.0 \%$ (v/ w) in the vegetative stage, the content increased during the flowering period, $1.4 \%$, while it decreased to $1.2 \%$ during the fruiting stage. The oil yield of the cultivated plants was $1.2 \%$ in the vegetative stage. It increased to a peak of $1.3 \%$ in the flowering stage, and was lowest $[0.8 \%(\mathrm{v} / \mathrm{w})]$ during the full fruiting stage. The dominance of the abundant components changed depending on the vegetative phases. Pulegone was prominent in the vegetative $(76.1 \%$ wild population, $62.7 \%$ cultivated population) and the flowering $(49.5 \%, 64.6 \%)$ stages, while menthone $(48.5 \%$, $65.3 \%$ ) contents were higher than pulegone $(34.7 \%$, $18.4 \%$ ) contents at the fruiting stage.

The roots of Echinacea purpurea (L.) Moench and Echinacea pallida (Nutt.) Nutt. (Asteraceae) grown in Denmark were analyzed by Thomsen et al. (2012) for their contents in lipophilic compounds and phenolic acids, depending on the season. Roots were sampled in early winter (December 15, 2009), early spring (March 23), late spring (May 25), summer (August 13), and mid-autumn (October 29) of 2010. A total of 16 
alkamides, two ketoalkenes, two ketoalkynes, and four phenolic acids (caftaric acid, chlorogenic acid, cichoric acid and echinacoside) were detected in alcoholic extracts by LC-MS and quantified by RPHPLC-DAD. Since the lipophilic compounds, alkamides in $E$. purpurea roots were dominant, while $E$. pallida was characterized by a dominance of ketoalkynes and ketoalkenes, the analysis of lipophilic compounds could be employed to distinguish the two species. The lowest levels of the main lipophilic compounds in roots of E. purpurea occurred in midautumn and early winter. The total contents of lipophilic compounds in E. pallida displayed a similar trend. Moreover, the contents of the main phenolic acids in E. purpurea peaked in spring. In E. pallida roots, echinacoside showed a significantly higher level in spring. Caftaric acid displayed a higher level in late spring, while cichoric acid reached a higher level from late spring to mid-autumn.

Menković et al. (2000) quantified xanthones and secoiridoids in aerial parts of Gentiana lutea L. (Gentianaceae) growing in Serbia. Wild plants were harvested every month from March until October at various stages of their development. The highest amounts of mangiferin and isoorientin occurred between June and July, and thus during the period of flowering. Lower amounts of mangiferin were detected in May and August, while there were only marginal changes in the isoorientin levels. In contrast, the highest amounts of isogentisin 3-O-primeveroside and isogentisin were observed in April and May respectively. In contrast, their amounts decreased significantly during the period of flowering. In October, the content of isogentisin 3-O-primeveroside again increased. It was concluded that during the period of flowering, leaves were rich in $C$-glycosides, while $O$-glycosides were mainly accumulated before flowering. In the case of secoiridoids, the content increased steadily during the vegetation period and reached maxima in October.

Seasonal variations in the contents of phenolics and antioxidant activities of Glechoma hederacea $\mathrm{L}$. (Lamiaceae) were analyzed by Varga et al. (2016). The aerial parts were collected from six Hungarian locations in April, July, and October 2012. Specimens harvested in July in a population originating from an open-site park in Budapest showed the highest total phenol content (115 mg gallic acid equivalent/g dry material) and the strongest antioxidant activity
(53.3 $\mathrm{mg}$ ascorbic acid equivalent/g dry material). Chlorogenic acid $(357 \mathrm{mg} / 100 \mathrm{~g})$ and rutin $(950 \mathrm{mg} /$ $100 \mathrm{~g}$ ) also reached the highest contents in July of samples from the Soroksár botanical garden population. In general, contents of the July collections were significantly higher than the ones from April and October. According to the results above, mid-summer was recommended as the best harvest time for ground ivy shoots.

Cheel et al. (2013) investigated the interactions of chemical profiles with biological activities of licorice, Glycyrrhiza glabra L. (Fabaceae) grown in the Czech Republic. Three thickened roots of four-year-old cultivated plants were sampled in every season of 2008. Total contents of phenols, flavonoids, and tannins showed peak amounts in November, August, and May, respectively. Liquiritin and glycyrrhizin, the main constituents, varied in the ranges between 28.762.8 and $41.8-114 \mathrm{mg} / \mathrm{g}$ dry weight, respectively. The relative proportions of glycyrrhizin glycoside, glabridin, glabrene, and liquiritigenin glycoside, varied in the ranges between $0.88-11.4 \%, 1.86-10.0 \%$, $1.80-18.4 \%$, and $5.53-16.3 \%$, respectively. These fluctuations were related to the antioxidant and free radical scavenging activities of licorice. It was found that the sample from May showed the strongest free radical scavenging effect and the highest gastroprotective effect, whereas the sample from November showed the best antioxidant effects. Liquiritin and glycyrrhizin, the main components with the highest proportion in February and May, were related to the superoxide radical scavenging and gastroprotective effects. Glabridin and glabrene, the main components in November, contributed to the antioxidant and DPPH scavenging activities of licorice.

Mártonfi et al. (2006) studied changes of natural products during three developmental stages of reproductive structures in Hypericum maculatum Crantz (Hypericaceae) growing in Slovakia. Generative parts of the taxon were harvested from three populations with different growing conditions. Remarkable differences in the concentration of natural products, in the various flower parts were noticed. During the whole period of flowering, the concentration of all the studied metabolites kept constantly in green flower parts (sepals). The most apparent variations were present in the flowering phase with the decrease of hyperoside and isoquercitrin concentration in petals, the decrease of the I3, II8-biapigenin concentration in 
stamens, and the increase of hypericin and pseudohypericin concentration in both petals and stamens. The flavonoids hyperoside and isoquercitrin, whose concentration decreased during flowering, presented the highest contents in the pistil.

Tekel'ová et al. (2000) studied seasonal changes in natural product content during the flower ontogenesis of Hypericum perforatum subsp. veronense (Schrank) H.Lindb. (Hypericaceae) grown in Slovakia. Samples were collected eight times in different plant development stages. The amount of dianthrones, derivatives of quercetin, and hyperforin increased from the first budding phase $(0.29 \%, 0.80 \%$, and $2.47 \%$, respectively) to the phase of freshly opened flowers $(1.04 \%$, $4.23 \%$ and $6.60 \%$, respectively). The amounts of dianthrones and quercetin glycosides then showed a decrease (in unripe fruits to $0.11 \%$ and $0.08 \%$, respectively), whereas the content of hyperforin increased to $8.07 \%$ in fruits. The amount of I3, II8biapigenin displayed an increasing trend from 0.21 in small buds to $1.04 \%$ in buds just before opening and subsequently decreased steadily to the lowest of $0.02 \%$ in fruits.

Pěnčíková et al. (2011) determined the seasonal and plant age related variation of isoquinoline alkaloids contents of Macleaya microcarpa (Maxim.) Fedde (Papaveraceae) grown in the Czech Republic. The aerial parts and underground parts and of thirteenyear-old plants were collected during the vegetative period from April to October. The major alkaloids in spring samples were sanguinarine and chelerythrine, their concentrations were two times higher compared to autumn samples. During the following vegetation period, the content of both benzophenanthridines slowly decreased. In contrast, the concentrations of protopine and allocryptopine showed a rather low level in spring and reached a maximum in July. Then protopine and allocryptopine in leaves dropped significantly to a very low level, but in October, at the beginning of vegetative quiescence, their contents increased again slightly. For most alkaloids in roots, the contents changed considerably during the vegetative cycle and reached the highest levels during June and July. Protopine showed the highest content in May, while macarpine culminated during July and August. The highest contents of alkaloids described above were two- to threefold higher than the contents of autumn samples. The contents of chelirubine and chelilutine reached the highest levels during June and
July. In addition, one-, two-, twelve- and thirteenyear-old plants were collected in October, at the end of the vegetative period to assess how plant age affects the content of alkaloids. Allocryptopine was the major component in both aerial and underground parts, but no obvious relation to the age of the plants was observed. Moreover, the authors found that minor chelilutine, chelirubine, macarpine, and sanguirubine were preferably accumulating in older roots.

Stochmal and Oleszek (2007) quantified variations in the contents of flavones identified in alfalfa Medicago sativa L. (Fabaceae), grown in Poland for three years (1999-2001). Aerial parts of ten plants were cut three times per year. Tricin and apigenin glycosides were the main flavonoids of alfalfa. Total content of flavonoids decreased gradually during seasons; the first spring cut displayed the highest concentration and this declined for the other two cuts. Simultaneously, the ratio of flavones acylated with hydroxycinnamic acids to non-acylated rose from 1.5 in the first to 1.8 for the other two cuts. This finding may indicate the relevance of acylated forms for the protection of plants against UV-B radiation during the summertime.

Skrzypczak-Pietraszek and Pietraszek (2012) studied seasonal variation of phenolic acid content in Melittis melissophyllum L. (Lamiaceae) growing in Poland. M. melissophyllum was sampled in two different habitats in May and September. Phenolic acid profiles of methanolic extracts were analyzed by HPLC-DAD. $p$-Hydroxybenzoic acid and $p$-coumaric acid were the main components, both of them showed higher levels of September samples than May samples in the same localities.

Skrzypczak-Pietraszek and Pietraszek (2014) also studied seasonal variations of flavonoid concentration in Melittis melissophyllum L. (Lamiaceae) growing in Poland. Plants were collected and separated into leaves and flowers in May and September. The highest total content of flavonoids was revealed in flowers (258 - 271 mg/100 g dry weight) and leaves (143$155 \mathrm{mg} / 100 \mathrm{~g}$ ) collected in May, the lower ones were recorded in leaves obtained from September (83$92 \mathrm{mg} / 100 \mathrm{~g}$ ). Geographical location had no obvious effect.

Grulova et al. (2015) recorded seasonal changes of the major constituents in essential oils of Mentha $\times$ piperita L. (Lamiaceae) cultivated in Slovakia. Plant material was collected monthly from April to 
September throughout three years. $97.1-98.7 \%$ of the total essential oil was based on menthol, menthone, limonene, menthyl acetate, menthofurane, and $\beta$ caryophyllene. The quantities of limonene in the same month of different years showed a decreasing tendency, the quantity decreased from 10.8 (April 2010) to $8.0 \%$ (April 2012) and from 3.2\% (September 2010) to $2.3 \%$ (September 2012). In 2010, the menthone amount increased from April $(15.3 \pm 1.8 \%)$ to August $(20.4 \pm 0.4 \%)$ and decreased to $14.1 \pm 1.1 \%$ in September. The tendency was different from 2011 and 2012. Menthone displayed the maximum accumulation at the beginning of the developmental stages (April 2011 and May 2012), while the lowest content was present in September of 2011 and 2012. The percentage of the major component, menthol, increased in 2010 and 2012 from April until July and decreased in September. This compound also showed an increasing tendency from April to August in 2011. The lowest levels of menthyl acetate were recorded in July 2011 and in August 2010 and 2012. The content of $\beta$-caryophyllene increased in May and June of the first two years followed by a sustained decline until the end of the year. During the three-year experiment, the seasons 2011 and 2012, had a higher mean temperature than in 2010; moreover, intense rainfalls in July 2011 and 2012 were recorded. The presented data imply that $M . \times$ piperita experienced different rain and temperature regimes, resulting in significant quantitative changes in essential oil composition.

Lubbe et al. (2013) studied the seasonal pattern of alkaloids in the bulbs, leaves, and roots of Narcissus pseudonarcissus L. cv. "Carlton" (Amaryllidaceae) grown in the Netherlands. Twenty-four plants were collected as followed points: (1) when shoots had emerged and were about $10 \mathrm{~cm}$ above ground, (2) before flowering, (3) during full flowering, (4) after flowering, and (5) after shoot senescence. Alkaloid contents of plants were monitored by quantitative ${ }^{1} \mathrm{H}$ NMR during the growing season. The average galanthamine and haemanthamine concentrations in bulbs reached a maximum before flowering. The concentration showed a decreasing tendency during and after flowering, but increased slightly again at the end of growing cycle. Narciclasine was present in the bulbs with highest amount in the second and third time points, and thereafter gradually decreased. In the leaves, the concentration of haemanthamine fluctuated with highest level before flowering. Extracts of leaves contained similar levels of galanthamine and narciclasine, which showed consistent concentrations until the third time point, followed by a decrease afterwards. In the root, galanthamine and haemanthamine showed different variety patterns, galanthamine accumulated higher concentrations until before flowering, whereas haemanthamine showed significantly higher concentrations after senescence.

Krzyżanowska-Kowalczyk et al. (2018) compared the metabolite profiles of Pulmonaria officinalis L. (Boraginaceae) collected in Poland in spring and autumn. Spring samples were characterized by the dominance of rutin, nicotiflorin, and 3-O-caffeoylthreonic acid. Salvianolic acid $\mathrm{H}$, actinidioionoside, three isomers of coumaroylquinic acid, and pulmonarioside B were the major components in autumn samples. Quantitation data obtained by HPLC-MS were analyzed by univariate volcano plot analysis, combining t-tests and fold change examination and unsupervised principal component analysis (PCA) to determine several features linked with spring and autumn samples of Pulmonaria officinalis. A clear separation of samples was achieved with both approaches.

Lakušić et al. (2011) studied the chemical composition of Satureja horvatii Šilić (Lamiaceae), cultivated in Serbia (the taxon is naturally occurring in Montenegro) at different phenological stages. Essential oil yields varied from $0.5-1.3 \%$. The lowest oil yield $(0.5 \%)$ occurred before flowering in April, and the highest (1.3\%) was recorded during late flowering and at the beginning of fruiting in September. The essential oil from samples obtained before flowering was dominated by linalool (37.4\%), thymol (27.3\%), and carvacrol (12.2\%). In the flowering period (June), the proportion of linalool increased up to 56.6$57.5 \%$, while that of thymol decrease to $15.5-15.8 \%$, carvacrol significantly dropped to $1.4-1.5 \%$. The essential oil sampled from fruiting stage (September and October) was dominated by linalool (58.4 and $65.8 \%$ ), followed by lower levels of thymol (7.6 and $1.3 \%)$, and carvacrol (0.7 and $0.1 \%)$. The authors also focused on differences between plant growing conditions. In Mediterranean natural habitats, the main oil components were the phenols thymol $(63.7 \%$ for the Mt. Orjen in Montenegro) or carvacrol (68.1\% for the Mt. Lovćen in Montenegro), while the oils from plants cultivated in temperate Belgrade were represented by linalool (up to $65.8 \%$ and $55.9 \%$ on average). 
Šebrlová et al. (2015) studied Stylophorum lasiocarpum (Oliv.) Fedde (Papaveraceae) grown in the Czech Republic and its seasonal variation in alkaloid composition. Three individual plants of one- and twoyear-old cultures were randomly harvested during the vegetation period from May to October. The extracts of the aerial part were characterized by a dominance of protoberberine alkaloids: coptisine, and stylopine, which were irrespective of the plants' age and time of harvest. Higher levels of all alkaloids were present in roots than in the aerial parts. The levels of most alkaloids peaked in the middle of the vegetation period.

Raudone et al. (2017) studied phenological changes in triterpenic and phenolic composition of Thymus L. species (Lamiaceae) grown in Lithuania. The aerial parts of plants were harvested at different ontogenetic stages from May to September of 2016. The phenolic compounds accumulated the highest amounts during budding and full flowering. Amounts decreased during fruiting and displayed the lowest levels at the end of the vegetation period. Rosmarinic acid was the dominant component in all Thymus species tested, ranging from $6.3 \mathrm{mg} / \mathrm{g}$ to $28.8 \mathrm{mg} / \mathrm{g}$. During full flowering, T. longicaulis C.Presl $(28.8 \mathrm{mg} / \mathrm{g})$ and T. $\times$ oblongifolius Opiz $(28.3 \mathrm{mg} / \mathrm{g})$ had the highest concentrations of rosmarinic acid, followed by T. $\times$ citriodorus Schweig. et Korte and T. pulegioides L. In contrast, $T$. sibthorpii Benth. and $T$. serpyllum L. possessed the lowest amounts, $9.32 \mathrm{mg} / \mathrm{g}$ and $11.7 \mathrm{mg} / \mathrm{g}$, respectively. After full flowering, the level of rosmarinic acid declined slowly during the fruiting stage. At the end of vegetation, the concentration of rosmarinic acid decreased significantly, and the final concentrations were in the following order in the investigated Thymus species ( $T$. longicaulis $>T$. pulegioides $>T \times$ oblongifolius $>T \times$ citri-

odorus $>T$. austriacus $>T$. praecox subsp. arcticus $>T . \quad$ sibthorpii $>T . \quad$ serpyllum). The concentration of ursolic acid was higher than that of betulinic, corosolic, and oleanolic acid. The accumulation pattern of these triterpenic acids varied significantly and depended on the particular Thymus species investigated.

\section{Cold climate}

Khodorova et al. (2013) studied the biosynthesis, compartmentation, and seasonal dynamics of benzylisoquinoline alkaloids from Corydalis bracteata (Steph. ex Willd.) Pers. (Papaveraceae). Different organs of plants were collected in St. Petersburg, Russia during the whole year. The investigated plant is a geophyte, which has a very short spring vegetation period, and for the rest of the year survives as an underground tuber with buds. During the whole year, the tuber is gradually replaced as follows: at the end of August, a new tuber inside the tissues of the old one was formed. In September, the tubers include the present year's tuber and the new developing one, which continues to grow to the next spring. In February, the cells of the old tuber start to degenerate and till the middle of May, the old tuber falls off, the new tuber continues to grow.

The highest levels of alkaloids was reached in whole plants (aerial parts plus underground tubers/roots) in April when leaves and flower buds developed most intensively. At this stage, 58\% of all alkaloids were restricted to the tuber, $37 \%$ came from the aerial part (buds, leaves, stem), and the other $5 \%$ were from the root. The total alkaloid amount in C. bracteata plants declined afterwards. Total alkaloid amount in tubers varied between about 0.70 and $5.18 \mathrm{mg}$, contributing $23-100 \%$ of the total content of alkaloids in plants, according to the plant phases. Also, the old tuber contributed $68-79 \%$ of the total amount. Thus, a significant decrease in alkaloids in tubers coincided with the loss of the old tuber. During the aboveground vegetation period, $45-58 \%$ of the sum of alkaloids was present in the aerial parts, with the highest percentage in stems and flowers. In August, during autumn and winter, the contents of alkaloids were rather low in the bud.

When whole plants were fed with the isotopically labeled tracer, $\left[\right.$ ring- $\left.{ }^{13} \mathrm{C}_{6}\right]$-tyramine, via the roots, the alkaloids became labeled in the roots only. However, when detached roots, leaves, tubers, and stems were exposed to $\left[\right.$ ring- $\left.{ }^{13} \mathrm{C}_{6}\right]$-tyramine, the label was detected in all organs. This indicated the absence of long-distance translocation of alkaloids between organs of C. bracteata, while the cell-to-cell transport of alkaloids is viable in the tuber via the apoplast. Differing from other benzylisoquinoline alkaloids producing species, each organ of $C$. bracteata 
possessed the capability of de novo biosynthesis of the full set of alkaloids.

Tuominen and Salminen (2017) qualified hydrolyzable tannins, flavonol glycosides, and phenolic acids of Geranium sylvaticum L. (Geraniaceae) growing near Turku, Finland. Seasonal, ontogenic, intra-plant and living condition-related variations of the phenolic compounds of G. sylvaticum organs were investigated. To study the variation of phenolics within individual plants, larger basal rosette leaves and smaller stem leaves were sampled. The results showed that geraniin was present at the same level $(153 \mathrm{mg} / \mathrm{g})$ in the stem leaves and basal leaves, when all populations and months were analyzed together. The leaf specimens were obtained from four populations with different growing conditions to determine the variation in polyphenol contents. Generally, it seemed that stressful conditions, such as high light and dryness, induced a higher level of polyphenols in a sunny roadside population and a sunny meadow than in other shadowed forest populations, although the locations were close to each other. To study seasonal variation in whole plants and leaves, samples from three different growing stages (small, medium, large) were collected, in total 16 individual samplings, five in five-day intervals in May and June, three in July, two in August, and one in September from four different populations each. The contents of geraniin in leaves culminated in July after the flowering period had ended and the seeds were in the maturing phase. Young small-sized leaves accumulated remarkably higher geraniin levels than medium and large leaves in summer sampled in all populations. Moreover, the seasonal patterns of carpinusin, galloyl-hexahydroxydiphenoyl-glucose B, digalloyl-hexahydroxydiphenoyl-glucose, and geraniinic acid were similar to that observed with geraniin. However, the amounts of ascorgeraniin and chebulagic acid increased more than threefold toward the end of the growing season in autumn. The content of these compounds was higher, particularly in old large-sized leaves. The level of quercetin derivatives in leaves showed maximum accumulation in spring and declined to half towards fall. The content of kaempferol derivatives kept constant throughout the season. The authors also provided some conclusions of various trends in G. sylvaticum organs. The optimal time to harvest petals was during the budding phase, with rare sylvatiins and other hydrolyzable tannins. Moreover, because of the low content of interfering compounds, the sepals were found to be a good source of carpinusin. In terms of the isolation of gallotannins, pistils during the fruiting phase, before seeds are mature could be considered. Proanthocyanidins and galloyl quinic acids might be extracted from roots as their content kept stable throughout the summer.

\section{Shrubs and subshrubs}

Some aromatic shrubs/subshrubs mainly in the Lamiaceae family, which includes many medicinal and culinary herbs, were reviewed in this section. Aromatic plants, especially rosemary and sage are well studied. The interest in these species is related to the multiple uses of the plants as spices, food ingredients as well as in the pharmaceutical and cosmetics industries.

\section{Mediterranean climates}

Leaves of the sub-shrub Digitalis obscura L. (Plantaginaceae) growing in Spain were analyzed by RocaPérez et al. (2004) for seasonal cardenolide accumulation and Dop5 $\beta r$ gene expression. Leaves for cardenolide analyses were collected in May, July, October 2000, and February 2001. The lowest concentration of cardenolide was present in May, increased rapidly during summer, then decreased in autumn, and remained constant in winter. The researchers also analyzed the seasonal expression of the gene encoding enzyme progesterone $5 \beta$-reductase, which produced the required $5 \beta$-configured precursors for cardenolide biosynthesis. The expression pattern showed a similar tendency as above, accumulation from February to July and a further decrease in autumn, although adverse climatic conditions seem to induce overexpression.

Guedes et al. (2004) investigated the seasonal dynamic of the essential oil content and composition in leaves of Hypericum androsaemum L. (Hypericaceae) cultivated in Portugal. Shrub samples were harvested every two months of a year. The essential oil yield varied between $0.7 \mathrm{mg} / \mathrm{g}$ (September) and $3.4 \mathrm{mg} / \mathrm{g}$ dry weight (February). In September, the essential oil had the lowest concentration of sesquiterpene hydrocarbons, $43 \%$, and the highest level of 1-octene and 2-hexenal, 38\%. In February, the essential oil contained the highest level of sesquiterpene 
hydrocarbons, $73 \%$, and the most pronounced variety of intermediate to long-chain $n$-alkanes and 1-alkenes.

The chemical composition of essential oil of Rosmarinus officinalis L. (Lamiaceae) growing in Sardinia in Italy was investigated by GC-MS (Melito et al. 2019). Aerial parts of five $R$. officinalis accessions were harvested monthly through a full year. The essential oil yield of all populations was in a range of $0.29 \%$ to $0.89 \%$. The lowest essential oil percentage was observed in Monte Doglia sample (altitude: $400 \mathrm{~m}$ ), while the highest essential oil content was observed in Porticciolo (altitude: $0 \mathrm{~m}$ ). Concerning seasonality, overall, the analyzed plants displayed the highest essential oil yield in summer in all populations. However, the minimum oil yield was found in samples of Monte Doglia (altitude: $200 \mathrm{~m}$ ), Capo Caccia (altitude: $0 \mathrm{~m}$ ), and Porticciolo (altitude: $0 \mathrm{~m}$ ) in winter, whereas higher altitude $(400 \mathrm{~m})$ Monte Doglia samples showed lowest contents in spring. The relative composition of main oil components showed significant seasonal variations. $\beta$-Pinene and bornyl acetate displayed the highest levels during spring $(6.8 \%$ and $4.8 \%$ ), while the lowest levels were observed in autumn $(3.1 \%$ and $0.8 \%)$; the maximum concentrations of $\gamma$-terpinene $(0.8 \%)$ and terpinolene $(0.7 \%)$ occurred during summer, while in winter and autumn, these compounds were missing $(0.0 \%)$.

Serralutzu et al. (2020) studied the essential oil yield and oil composition of $R$. officinalis during the flowering phase growing in Italy. Specimens were collected in the whole year of 2018. After transplanting, two plant types were evident differing in phenology: type 2 featured a later and shorter flowering time in comparison to type 1 . The essential oil yields of type 1 plants decreased from $0.77 \%$ in winter with flowering plants, to $0.13 \%$ in November when flowering is ended. The type 2 plants showed a range from $0.16 \%$ in September to $0.06 \%$ in November. $\alpha$-Pinene was always the predominant compound in every season, ranging from 48.0 to $75.4 \%$ in type 1 plants and from 18.2 to $52.9 \%$ in type 2 plants. The other major constituents of essential oil were borneol, camphene, caryophyllene, eucalyptol, and verbenone. In type 1 plants, eucalyptol increased from winter to spring and then decreased. Borneol, camphene, caryophyllene, and verbenone showed increasing trends in February and April. $\alpha$-Pinene displayed an increasing trend from spring to autumn and irregularly varied in winter. The type 2 plants displayed a decrease in $\alpha$-pinene and camphene and an increase in borneol, caryophyllene, and eucalyptol in November at the end of flowering.

Salido et al. (2003) investigated the composition of essential oil samples, obtained by steam distillation of twigs of rosemary ( $R$. officinalis) collected in four different Southern Spanish localities. Samples were harvest during three phenological stages: full flowering (April), fruiting (June and July), and hibernation (December) period. Oil yields ranged from 1.0 to $1.8 \%$, with the highest percentages during the fruiting period. Concerning the oil composition, the monoterpene hydrocarbons content in the Las Chozuelas (altitude: $1150 \mathrm{~m}$ ) and El Vadillo-Castril (altitude: $1050 \mathrm{~m}$ ) populations declined from full flowering to fruiting and showed the highest proportion afterwards in winter. This maximum of monoterpenes in winter was also observed in the Garganta de Hornos (altitude: $1000 \mathrm{~m}$ ) and Peria del Olivar (altitude: $800 \mathrm{~m}$ ) populations; but it remained at a high level during fruiting. Oxygenated monoterpenes levels showed a complementary trend, which reached their maximum during fruiting, for Las Chozuelas and El VadilloCastril, and their minimum, for Garganta de Hornos and Peria del Olivar during the same period. More homogeneous trends were observed for the sesquiterpene group as a slow decrease over the year for all populations, except for the El Vadillo-Castril population. Camphor accumulated higher contents in full flowering or fruiting than in hibernation. The $\alpha$-pinene level reached a maximum in winter (except for Garganta de Hornos), while the opposite was observed for $\beta$-pinene. However, the 1,8-cineole level stayed constant during the growing cycle. The levels of other oil compounds varied seemingly randomly throughout the study, except for myrcene, which showed a peak during fruiting.

Papageorgiou et al. (2008a) studied the seasonal changes in essential oil and the phenolic composition as well as antioxidant activity of Lamiaceae species, Rosmarinus officinalis and Salvia fruticosa Mill. collected in Greece. Aerial parts of the two plants were collected at the end of February, May, and August of 2005 and 2006. The essential oil yields steamed from $R$. officinalis leaves were in the range of 1.8 to $3.3 \% \mathrm{v} / \mathrm{w}$ (dry weight). The minimum oil yield was recorded in February for both years. Moreover, the essential oil composition of rosemary remained steady during the years investigated. The oil yield of sage ranged from 1.6 to $3.2 \% \mathrm{v} / \mathrm{w}$. The lowest yields 
were recorded during May (flowering period) of 2005 and during February (before flowering period) for both years. Neither the year nor the season influenced the proportions of the major constituents apart from camphor, viridiflorol, and manool which varied significantly. Regarding methanolic extracts, the contents of quercitrin and luteolin in rosemary and sage revealed a peak in May (flowering period) for both years and then declined. But rutin was found only in rosemary extracts, which declined with the development of plants. In the case of phenolic acids of both species, the lowest content of caffeic acid was found during May 2005 and 2006, whereas the highest content was detected in August (late fruiting). About rosmarinic acid, both extracts showed analogous trends during 2006 (but not in 2005), presenting lower levels in May and higher levels in August. Rosmarinic acid obtained from both plant extracts showed the maximum accumulation in February (before flowering).

Free radical-scavenging activity of sage oil was much higher [2.4-5.2 g/l (oil concentration)] than of that measured for pure compounds such as 1,8-cineole (not active), $\alpha$-pinene (not active), and $\beta$-caryophyllene $(18.6 \mathrm{~g} / \mathrm{l})$. The $\mathrm{IC}_{50}$ values of rosemary oil were similar to those of sage. The rosemary phenolic extracts established the highest antioxidant activity during February [12.4 mg/l (extract concentration)], whereas the lowest was detected during May 2005 (43.2 mg/l). In 2006, the strongest antioxidant activity was measured in August $(22.9 \mathrm{mg} / \mathrm{l})$. About the phenolic extracts of sage sampled from 2005, the lowest antioxidant activity was detected during February and August (about $25 \mathrm{mg} / \mathrm{l}$ ). For 2006, a significantly stronger $\mathrm{IC}_{50}$ value was observed in August $(21.3 \mathrm{mg} / \mathrm{l})$, while the lowest value was measured during February $(42.1 \mathrm{mg} / \mathrm{l})$.

Generalić et al. (2012) studied seasonal dynamics of phenolic content, antioxidant capacity, and antibacterial activity of Dalmatian sage, Salvia officinalis L. (Lamiaceae), growing in Croatia. Leaves were sampled and quantified by HPLC in February, May, August, and November of 2008. For all varieties, the highest total phenolic contents, as well as the highest flavonoid and flavone and flavonol, were measured in the extract of plants harvested in May, where flavonoids amount was two times higher than the February sample or the November sample and more than four times higher compared to the August sample.
The dominant compound in all extracts was rosmarinic acid, the lowest amount of it was found in May, the highest amounts of the other identified phenolic acids, syringic acid, $p$-coumaric acid, and caffeic acid were found in February. However, the amounts of these compounds were significantly lower compared to the ones of rosmarinic acid. The presence of stilbenes such as resveratrol and astringin also reached their highest amounts $(4.7 \mathrm{mg} / \mathrm{l})$ in May. The contents of catechin and epicatechin were greatly influenced by the phenological phase. Concerning biological activity, samples harvested from May, with the highest amount of flavonoids, showed the strongest antioxidant and antimicrobial activities.

Santos-Gomes and Fernandes-Ferreira (2001) studied organ- and season-dependent variation in the essential oil composition of Salvia officinalis L. (Lamiaceae) grown in Portugal. Above-ground parts from 8 to 12 plants were randomly sampled in each of the two experimental fields at Arcos de Valdevez and Arouca in July, October, and December 1998, and in February, April, and July 1999. The dominant essential oil component in the vegetative parts was $\alpha$ thujone, which represented 25.5 and $55.1 \%$ of the essential oils from sage leaves and stems, respectively. In flowers, $\alpha$-thujone, 1,8 -cineole, and $\beta$-pinene contributed a similar proportion of around $17.0 \%$. The essential oil contents differed significantly over the year both in the two localities. In Arouca, the oil yields ranged from $19 \mathrm{mg} / \mathrm{g}$ of dry weight (October) to $51 \mathrm{mg} / \mathrm{g}$ (December). In Arcos de Valdevez, the highest oil yields were present in July of both years for around $100 \mathrm{mg} / \mathrm{g}$ ) and the lowest in April $(9 \mathrm{mg} /$ g). Concerning the chemical composition of essential oils obtained from the Arcos de Valdevez experimental site, the proportion of monoterpene hydrocarbons increased from 8.2 in December to $22.1 \%$ in April and from 11.1 to $16.7 \%$ in Arouca. Oxygen-containing monoterpenes revealed the widest variations. The proportion of this group compounds displayed a declining tendency from 71.5 to $43.0 \%$ in Arcos de Valdevez and from 67.4 to $42.0 \%$ in Arouca from December 1998 to April 1999. The second broadest variation was observed for the proportions of the sesquiterpene hydrocarbons, which ranged from 7.3 to 19.3\% from February to April in Arcos de Valdevez and from 7.1 to $21.9 \%$ in Arouca. From July 1998 to February 1999, the percentage of oxygen-containing sesquiterpenes was in the range of $4.5-8.4 \%$ and from 
5.4 to $11.2 \%$ in Arcos de Valdevez and Arouca, respectively.

In an investigation related to the topic at hand, Usano-Alemany et al. (2012) studied the seasonal variation of the essential oils of Salvia officinalis subsp. lavandulifolia (Vahl) Gams (Lamiaceae) growing in Spain and their role in the protection from bacteria. Aerial parts were harvested from four years old plants during the full vegetative cycle. This variation showed a peak just after flowering time (autumn) and reached the lowest point just before flowering time. Monoterpenes were the dominant compound group, representing more than $80 \%$ of the total compounds. Low molecular weight compounds, such as the highly volatile monoterpene hydrocarbons were recorded in high percentages during summer, contributing almost half part of the total compounds. Generally, higher antimicrobial activity of essential oils obtained from winter and autumn plants was observed, this might be explained by the higher content of camphor and borneol.

Oil composition and variations during the vegetative cycle of two different age cultivars of Thymus vulgaris L. (Lamiaceae) cultivated in Italy were analyzed by Hudaib et al. (2002), in order to choose the optimal collection (harvest) period of thyme. Aerial parts from young plants (two years old) were collected on: 5 June, 3 July, 24 July, 6 December of 1999, and from old plants (five years old) were collected on: 5 June, 3 July of 1999. Young plants had the highest oil content (1.2\%) during the July/August harvesting period. In comparison to the older cultivated plants, young $T$. vulgaris plant had a markedly higher essential oil content. Regarding the oil composition, the maximum percentages of phenols in young plant oils were found in June/July, the lowest levels were recorded in November/December. In contrast, monoterpene hydrocarbons showed the opposite trends in both collection periods. In samples of older plants, both compound groups (monoterpene hydrocarbons and phenols) also showed similar tendencies. For the other minor components, a higher content was generally recorded in November/December.

\section{Temperate climates}

Lakušić et al. (2013a) studied seasonal variations in the composition of the essential oils obtained from rosemary (Rosmarinus officinalis) cultivated in Serbia by GC and GC/MS. Plants were sampled monthly from April 2008 to May 2009. The oil yields ranged from 0.2 to $1.0 \%$. The highest oil yields were detected in young shoots and the lowest values were found during fruiting. Except for seasonal dynamics of individual compounds of the essential oils, the researchers used cluster analysis and showed that all collected samples can be classified into three main clades, which have different essential oil compositions. In clade I (shoots with fruits) and Clade III (shoots with developed leaves) camphor was dominating. In clade II (shoots with young and incompletely developed leaves) the content of camphor was equal to that of 1,8 -cineole.

Luis and Johnson (2005) studied seasonal variations of rosmarinic acid and carnosic acid in rosemary leaf extracts grown in the southern UK. Rosmarinus officinalis was sampled at the beginning and the end of each month before 9 am, between winter 2001 and winter 2002. The concentrations of carnosic acid decreased by $50 \%$ during the summer months, when

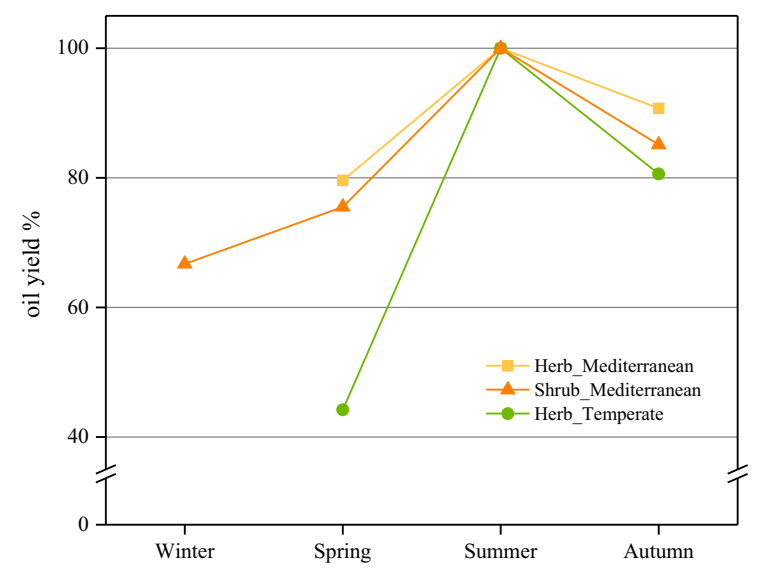

Fig. 3 Patterns of seasonality of essential oil yield in herbs (aerial parts/leaves) of Mediterranean climate (yellow line) and temperate climate (green line) and shrubs (aerial parts/leaves) of Mediterranean climate (orange line). Note: Oil-bearing herbs are usually in senescence stage in winter. *Numbers on the $\mathrm{x}$-axis indicate four seasons during ontogenesis. Numbers on the $\mathrm{y}$-axis indicate percentages of a given oil yield/compound class as percentages of the seasonally maximum values. Calculation method: the percentage values of a given oil yield/compound class of different seasons were calculated from each literature reference, and then numbers of each season (have similar change tendency, sample size $>10$ ) were averaged based on different climates/whole Europe, and the average values per season were finally expressed as a percentage of the average seasonal maximum value 
the highest temperature and lowest precipitation rates were recorded. Then it showed an increasing tendency during September, October, and November and reached the highest levels in December. Rosmarinic acid levels displayed a slight increase during the summer, and showed a peak in September, and stayed constant during the rest of the year.

Lakušić et al. (2013b) also studied changes in essential oil yields and compositions of Salvia officinalis (Lamiaceae) during the vegetative phases. Ten oil samples were collected separately from two cultivars grown in Serbia with different geographical origins (Serbia and Croatia) throughout the complete growing cycle. The cluster analysis showed that the composition of the essential oils was influenced by leaf age and origin of the plants. All oil samples were classified into two groups. The first group contained samples obtained from April to June (young leaves) belonging to the $\alpha$-humulene type. The second group was represented by the camphor and thujone type, including oil samples from mainly old leaves (August to June). In the second group, samples originating from Croatia and Belgrade can be further separated.

Grausgruber-Gröger et al. (2012) investigated the seasonal influence on the formation of the main monoterpenes and the gene expression of monoterpene synthases in Salvia officinalis grown in Austria. Leaves were always harvested from two cultivars throughout the vegetative period at monthly intervals from June to October. Plants were investigated at the level of mRNA expression, analysed by qRT-PCR, and at the level of end-products, analysed by gas chromatography. Cultivar and season had a significant impact on monoterpene synthases and monoterpenes. The levels of 1,8-cineole synthase and its end product 1,8-cineole kept stable until August and dropped marginally afterwards. The thujones accumulated gradually during the phenological stages. However, the transcript level of their corresponding terpene synthase reached the highest in the middle of the phenological stages and then decreased. Only camphor levels were accurately correlated with the mRNA level of the corresponding terpene synthase.

\section{Discussion}

From the partially contradictory data reviewed above, it is obvious that seasonal variation of plant natural

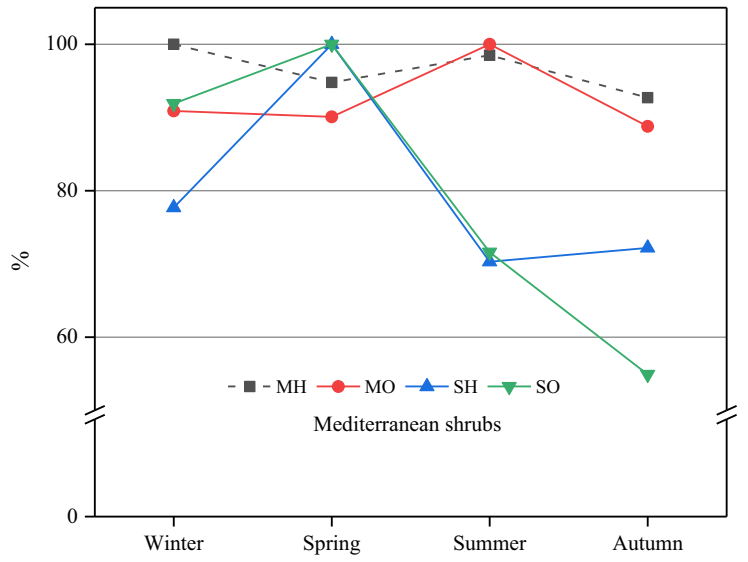

Fig. 4 Patterns of seasonality of different compound classes in essential oils in Mediterranean shrubs/subshrubs (aerial parts/ leaves). $\mathrm{MH}, \mathrm{MO}, \mathrm{SH}, \mathrm{SO}$ represent monoterpene hydrocarbons $\mathrm{MH}$, oxygen-containing monoterpenes MO, sesquiterpene hydrocarbons $\mathrm{SH}$, and oxygen-containing sesquiterpenes $\mathrm{SO}$, respectively. Note: Dash line means pattern not reliable. *Same as the description of Fig. 3.

products is a very intricate topic, because contents of natural products are influenced by both abiotic and biotic ecological factors. It is also noticeable from the collection of data highlighted above and in Table 1 that a very high ratio of literature focusing on either content or composition of essential oils, or on phenolics, such as phenolic acids and flavonoids. Both facts are explained by the important role of these compound classes as bio-actives and thus their commercial interest. Additionally, these compounds can be relatively easy obtained and analysed. Less polar compounds, which are not volatile are not as well studied, though they will be for some taxa ecologically more relevant.

Based on the above data, some first trends can be derived. These are displayed in Figs. 3-5. In Mediterranean climates, many herbs and shrubs are rich in essential oil. There seems to be a trend for both herbs and shrubs growing/grown either in Mediterranean climates or temperate climates to yield higher contents of essential oils in summer (Fig. 3). The oil yields display similar changes during seasons, increase gradually with development and then decrease. However, the changes in the Mediterranean climate are less pronounced than in the temperate climate. Relative oil yields of herbs/shrubs growing/grown in Mediterranean climates are always higher than for the same species grown in temperate climates, except in 
summer. This corroborates the fact that at lower latitude, i.e. further south, populations usually contain higher concentrations of essential oils (FernándezSestelo and Carrillo 2020). Particularly in autumn, the oil yield is still very high in populations from Mediterranean climates. Therefore, summer or autumn are both suitable for harvesting plants for essential oil production in Mediterranean climates, e.g. from the genera Artemisia, Hypericum Origanum, Satureja, and Thymbra (Jerković et al. 2001b; Llorens-Molina and Vacas 2015; Milos et al. 2001; Schwob et al. 2004; Stefanaki et al. 2018) as well as from the sub-shrub genera Rosmarinus, Salvia, and Thymus (Hudaib et al. 2002; Melito et al. 2019; Papageorgiou et al. 2008a; Salido et al. 2003; SantosGomes and Fernandes-Ferreira 2001; Serralutzu et al. 2020; Usano-Alemany et al. 2012). In contrast, summer is more suitable for harvesting essential oil yielding herbs in temperate climates, e.g. from the genera Clinopodium, Mentha, and Satureja (Grulova et al. 2015; Lakušić et al. 2011; Slavkovska et al. 2013). Notably, the highest yields were usually observed in summer during the flowering stage. This could be the result of higher oil production from reproductive tissues, and/or higher temperature stimulation, and/or UV radiation, and/or higher levels of protection required for reproductive structures. Additionally, volatiles emitted from flowers play a role in attracting species-specific pollinators, whereas the volatiles from vegetative parts, especially those

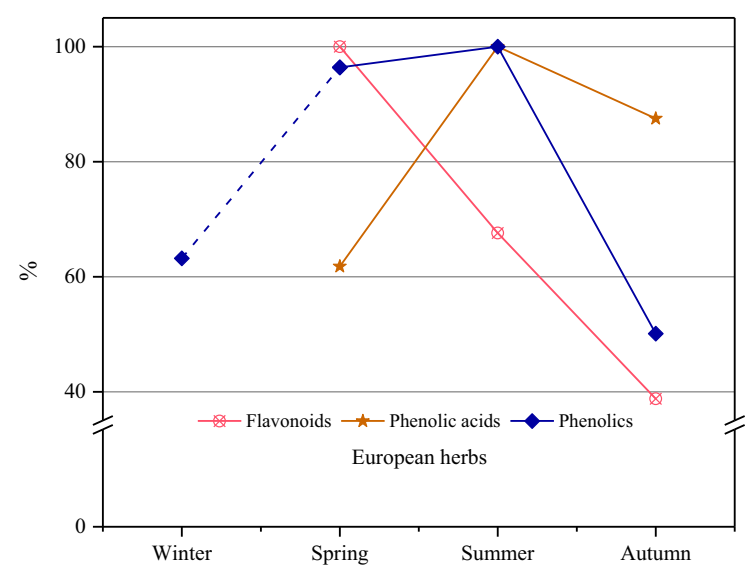

Fig. 5 Patterns of seasonality of flavonoids, phenolic acids, and phenolics in European herbs without classification into climate types. Note: Dashed line means the value of winter was calculated mostly from Mediterranean herbs. *Same as the description of Fig. 3. released after herbivory, appear to protect plants by deterring herbivores and by attracting the enemies of herbivores (Pichersky and Gershenzon 2002). Furthermore, it seems that herbs accumulate a higher percentage of essential oils than shrubs in spring and summer. This observation can probably be explained by the difference in life form, the shrubs' woody parts contribute to the plants' total weight, but usually contain only insignificant amounts of essential oil.

Four different patterns of seasonality of essential oil composition in shrubs/subshrubs growing/grown in Mediterranean climatic zones are summarized in Fig. 4. In essential oils, monoterpene hydrocarbons, oxygen-containing monoterpenes, sesquiterpene hydrocarbons, and oxygen-containing sesquiterpenes are the four main compound classes. The percentages of monoterpene hydrocarbons tend to reach peak values either in winter or summer. No repeatable patterns are found for monoterpene hydrocarbons, and therefore, the dashed black line in Fig. 4 is calculated from average values. The seasonal variation of oxygen-containing monoterpenes is more uniform, peak values are reached in summer, but high levels also occur in other seasons. Sesquiterpene hydrocarbons seem to fluctuate sharply, their contents peak in spring, decrease in summer, and then increase again during the cold seasons. Oxygen-containing sesquiterpenes display higher amounts in winter and spring and gradually decrease in summer and autumn. The above trends are based on experimental data obtained for Hypericum, Rosmarinus, Salvia, and Thymus (Guedes et al. 2004; Hudaib et al. 2002; Papageorgiou et al. 2008a; Salido et al. 2003; Santos-Gomes and Fernandes-Ferreira 2001; Usano-Alemany et al. 2012).

Some experimental data indicate that monoterpenes have a protective role against heat and oxidative stress (Loreto et al. 2004; Sharkey and Yeh 2001). This could partially explain the high monoterpene values during summer. In contrast, most of the sesquiterpenes are semivolatile liquids, associated with repellency of herbivorous insects, suggesting an "extended chemical defense" by these sesquiterpenoids for young, well palatable, herbs in spring (Himanen et al. 2010; Holopainen et al. 2013). Though relationships between hydrocarbon and oxygen-containing terpenoids are rarely studied, reciprocal regulation between $\alpha$-cadinol (oxygenated sesquiterpene) and $\delta$-cadinene (hydrocarbon sesquiterpene) during seasons was observed (Paolini et al. 2010). 
In the publications covered in this review, many of the Mediterranean herbs and shrub species were investigated for their contents in essential oils, whereas temperate herb species were mostly studied regarding their phenolic compounds (Table 1). This bias in study focus makes generalizations of trends across climate zones difficult. It is however obvious that environmental conditions strongly influence the expression of these constituents, including seasonal factors. Because of the insufficient number of samples in each climatic zone and the mentioned bias in studied classes of phytochemicals between climate zones, comparisons of trends in different climates are not possible.

Nonetheless, repeatable seasonal patterns in European herbs can still be observed. In spring as a low temperature season (above ground parts of temperate herbs usually do not exist in winter), high levels of flavonoids in the leaves and aerial parts of herbs are common; these levels then decrease during summer. In contrast, phenolic acid contents have their lowest concentrations in spring, and culminate in summer, followed by a slight decline in autumn (Fig. 5). The data to derive these trends stem from the genera Hypericum, Medicago, Melittis, Ruta, and Thymus (Filippini et al. 2010; Galasso et al. 2014; Generalić et al. 2012; Pacifico et al. 2016; Raudone et al. 2017; Skrzypczak-Pietraszek and Pietraszek 2012, 2014; Stochmal and Oleszek 2007). The harvesting time had a strong influence on the phenolic acids and accentuated that plants in the vegetative state accumulate higher levels of phenolic acids (Papageorgiou et al. (2008b). As the physiological states move towards reproduction, resources are reallocated, and the production of phenols is directed towards flavonoid production during flowering. Once the flowering stage is over and the vegetative growth resumes, the levels of phenolic acids begin to increase (Fletcher et al. 2010). Flavonoid production also seems to be linked to oxidative stress in plants (Pirie et al. 2013; Sousa Araújo et al. 2015). Isoprenoid emission and the level of enzymatic and non-enzymatic antioxidants were lower in summer than in spring (Nogués et al. 2012). However, from the existing experimental data, it cannot be decided whether the observed patterns are (only) reactions of the plants to changes in their (climatic) environment or whether ontogenetic factors also might play a (major) role.
During growth and development, plants synthesize large amounts of phenolics, which play a major role in adaptation to changing environments and in overcoming environmental stress; accordingly, concentrations of phenolics are also depending on the harvest date (Edreva et al. 2008). Data obtained from species of the genera Alchemilla, Clinopodium, Echinacea, Foeniculum, Geranium, Glechoma, Glycyrrhiza, Hypericum, Micromeria, Origanum, Pulmonaria, Ruta, Satureja, and Thymus indicate a trend towards higher concentrations of phenolics during spring and summer (Fig. 5) (Cheel et al. 2013; Duckstein et al. 2012; Filippini et al. 2010; Krzyżanowska-Kowalczyk et al. 2018; Pacifico et al. 2015, 2016; Scognamiglio et al. 2015; Thomsen et al. 2012; Tuominen and Salminen 2017; Varga et al. 2016). Identical trends were observed for the two main compound classes of phenolics, flavonoids and phenolic acids (Fig. 5).

One possible explanation for high levels of phenolic compounds in young herbs in spring is a protective effect of phenolics during the highly vulnerable juvenile stage, as herbivores preferably eat younger compared to older herbs (Barton and Koricheva 2010). Concentrations of phenolics were additionally positively correlated with temperature. Herbs may use temperature fluctuations across the season to fine-tune their biological circannual clock and to specifically regulate their chemical defenses (Huang et al. 2020). This is of importance for the plants, because attacks by herbivores including specific kinds and numbers of pathogens, insects, herbivores, and the consequent wounding of plant tissues, are all also depending on the season and ambient temperatures. Levels of individual phytochemicals or classes of phytochemicals are hard to predict, because such levels are influenced by ontogenetic factors as well as synergistically and antagonistically acting multiple environmental factors.

When comparing the seasonal patterns of herbs and trees (Zidorn 2018), some similarities can be detected. In leaves of deciduous trees, higher levels of phenolics appear in summer; this is in parallel with the yield of essential oils from herbs. In the Mediterranean zone, higher yields than in the temperate zone occur during the whole year. Young leaves in rosemary are reported to contain a higher amount of essential oil than older leaves; this is in parallel with the content of phenolics in young versus old leaves of deciduous trees (Lakušić et al. 2013a). 
Table 3 Recommended criteria for future seasonal studies

\begin{tabular}{lc}
\hline Aspect & Recommendations \\
\hline Analytics & $\begin{array}{c}\text { Modern analytical methods enabling identification and quantification of individual compounds } \\
\text { should be used wherever possible, i.e. methods determining only, e.g., the total phenol content } \\
\text { should be avoided and methods such as GC-FID, HPLC-DAD-MS, and qNMR should be } \\
\text { preferred. }\end{array}$ \\
$\begin{array}{c}\text { Biological repeats per point in } \\
\text { time }\end{array}$ & $\begin{array}{c}\text { As many as possible with a justifiable experimental effort, but at least six, otherwise statistically } \\
\text { valid data interpretation will usually not be possible, though seasonal effects might be present. } \\
\text { Collection time intervals }\end{array}$ \\
$\begin{array}{c}\text { Theoretically equal time intervals seem to be optimal. However, additional samplings in times of } \\
\text { dynamic seasonal plant development are recommended; e.g., when the standard sampling } \\
\text { interval is one sampling per month, in spring weekly samplings can be preferable. }\end{array}$ \\
$\begin{array}{c}\text { In order to study seasonal dynamics, all major developmental stages in the life of the plants or } \\
\text { studied plant organs need to be covered. Thus, usually at least around six samplings will be } \\
\text { needed at different times during the year. } \\
\text { Statistics }\end{array}$ \\
$\begin{array}{c}\text { Statistical methods used should be tailored to the studied scientific problem; great care should be } \\
\text { taken to clearly distinguish between analytical and biological repeats, respectively. Biological } \\
\text { repeats are essential to assess within population variation at any given point in time. }\end{array}$ \\
\hline
\end{tabular}

Additional studies on the seasonality of toxic compounds in European herb species, except for Corydalis, Macleaya, and Stylophorum, where some data already exist, seem to be required (Khodorova et al. 2013; Pěnčíková et al. 2011; Šebrlová et al. 2015). Moreover, seasonal changes in triterpenic acid contents were only reported in eight Thymus species by Raudone et al. (2017). Also, the contents of hydrolyzable tannins and lipophilic compounds (Thomsen et al. 2012; Tuominen and Salminen 2017) have been only rarely studied and the research on their seasonal variation is lacking in the cold zones of Europe.

The adaptability of plant morphology to the environment is relatively easy to observe and recognize; in contrast, adaptions in plant biochemistry are harder to observe and quantify (Yang et al. 2018). Nonetheless, there are some possible explanations for regularly found trends in the contents of bioactive natural products: (1) In the Mediterranean climate (characterized by higher temperatures and regularly occurring drought periods), different levels of pressure by microorganisms and relatively higher pressure by herbivores could be expected to induce the highest levels of phenolics in summer and/or the full-flowering stage, respectively. (2) Defence and repair mechanisms might be impaired in low temperatures. This might in turn trigger higher levels of compounds preventing damage from stress factors such as UV-B radiation, which (e.g. in high altitudes) might also act at low temperature.

In conclusion, seasonal variation is (a) species specific, (b) organ specific, (c) compound specific, (d) depending on region, habitat, altitude, and climate pattern, (e) flexible and reactive to ecological stresses, and thus often not primarily related to the season itself, and (f) seasonal variation might differ due to plant age.

Seasonal and maturity variations are interlinked with each other, because the specific ontogenic growth stage differs as the season progresses. Different species of herbs (even though of the same species) will not have consistent phenological patterns, due to climate differences and individual reactions to local ecological conditions.

To gain reliable and reproducible data in future studies, some minimum criteria for experimental designs should be met. The most important have been compiled in Table 3.

1) At least six individual plant samples should be collected from each population for each point in time. 2) The sampling method should include at least six different sampling points, ideally covering the entire life cycle of the plant or the investigated plant organ (e.g. leaves). 3) As the seedling and juvenile stages are short-lived and dynamic, sampling should be performed with a higher frequency during these times than at other stages of the plant development. 4) Important stages to be considered in the sampling 
protocols for all plant organs before budding, during budding, immediately after budding, during flowering, after flowering, and at the fruiting stage. 5) Modern analytical chemical techniques should be used to allow for quantification of individual compounds and not only compound classes (e.g., GC-FID, HPLC-DAD, and qNMR. 6) Statistical calculations including means and standard deviations as well as analysis of variance should be provided for all points in time. These should be based on real sample replicates and not only on analytical replicates of the same sample for each point in time. This is an important difference, because biological variation is usually much higher than analytical variation. Without a knowledge of the biological variation of the samples for a given point in time/phenological stage, any interpretations of seasonal variations are flawed from the start. 7) Studies of seasonal variation should encompass ideally more than one season in order to be able to determine, whether the observed patterns are reproducible between years or just chance observations valid for one particular year, only. In this context, detailed meteorological data for each of the studied years/ seasons are warranted.

Due to the increasing global mean temperature, climate zones are shifting (North in the case of Europe) (Mahlstein et al. 2013). E.g., the Mediterranean climate zone will gradually extend its range to areas further North in the European continent (Beck et al. 2018). The biosynthesis of natural products in herbs and shrubs is directly dependent on climaterelated variables (e.g., drought, herbivore stress); when stress conditions are persistent, species-specific survival in natural ecosystems will depend on adaptation strategies including ecophysiological, structural, and biochemical responses. To study seasonal trends of natural compounds from herbs growing/grown in different climate zones is thus a timely research topic, which might help to get a glimpse into the future in terms of the effects of climate change. In addition, experimental strategies to assess how herbs will respond to multiple aspects of climate change will be needed.

Acknowledgements Yan $\mathrm{Li}$ acknowledges the Chinese Scholarship Council (CSC) for scholarship [grant number 201708310148].

Open Access This article is licensed under a Creative Commons Attribution 4.0 International License, which permits use, sharing, adaptation, distribution and reproduction in any medium or format, as long as you give appropriate credit to the original author(s) and the source, provide a link to the Creative Commons licence, and indicate if changes were made. The images or other third party material in this article are included in the article's Creative Commons licence, unless indicated otherwise in a credit line to the material. If material is not included in the article's Creative Commons licence and your intended use is not permitted by statutory regulation or exceeds the permitted use, you will need to obtain permission directly from the copyright holder. To view a copy of this licence, visit http://creativecommons.org/licenses/by/4.0/.

Funding Open Access funding enabled and organized by Projekt DEAL.

\section{References}

Agerbirk N, Olsen CE, Nielsen JK (2001) Seasonal variation in leaf glucosinolates and insect resistance in two types of Barbarea vulgaris ssp. arcuata. Phytochemistry 58:91-100

Barton KE, Koricheva J (2010) The ontogeny of plant defense and herbivory: characterizing general patterns using metaanalysis. Am Nat 175:481-493

Beck H, Zimmermann N, McVicar T, Vergopolan N, Berg A, Wood E (2018) Present and future Köppen-Geiger climate classification maps at 1-km resolution. Sci Data 5:180214

Boege K, Marquis RJ (2005) Facing herbivory as you grow up: the ontogeny of resistance in plants. Trends Ecol Evol 20:441-448

Cheel J, Tůmová L, Areche C, van Antwerpen P, Nève J, Zouaoui-Boudjeltia K, San Martin A, Vokřál I, Wsól V, Neugebauerová J (2013) Variations in the chemical profile and biological activities of licorice (Glycyrrhiza glabra L.), as influenced by harvest times. Acta Physiol Plant 35:1337-1349

de Sousa Araújo TA, da Silva Solon LG, da Silva GA, das Graças Almeida M, da Costa JGM, de Amorim ELC, Albuquerque UP, (2015) Does rainfall affect the antioxidant capacity and production of phenolic compounds of an important medicinal species? Ind Crops Prod 76:550-556

Drøhse Høgedal B, Mølgaard P (2000) HPLC analysis of the seasonal and diurnal variation of iridoids in cultivars of Antirrhinum majus. Biochem Syst Ecol 28:949-962

Duckstein SM, Lotter EM, Meyer U, Lindequist U, Stintzing FC (2012) Phenolic constituents from Alchemilla vulgaris L. and Alchemilla mollis (Buser) Rothm. at different dates of harvest. Z Naturforsch C 67:529-540

Edreva A, Velikova V, Tsonev T, Dagnon S, Grel A, Akta L, Gesheva E (2008) Stress-protective role of secondary metabolites: diversity of functions and mechanisms. Gen Appl Plant Physiol 34:67-78

Fernández-Sestelo M, Carrillo JM (2020) Environmental effects on yield and composition of essential oil in wild populations of Spike Lavender (Lavandula latifolia Medik). Agriculture 10:626 
Filippini R, Piovan A, Borsarini A, Caniato R (2010) Study of dynamic accumulation of secondary metabolites in three subspecies of Hypericum perforatum. Fitoterapia 81:115-119

Fletcher RS, Slimmon T, Kott LS (2010) Environmental factors affecting the accumulation of rosmarinic acid in spearmint (Mentha spicata L.) and peppermint (Mentha piperita L.). Open Agr J 4:10-16

Galasso S, Pacifico S, Kretschmer N, Pan SP, Marciano S, Piccolella S, Monaco P, Bauer R (2014) Influence of seasonal variation on Thymus longicaulis $\mathrm{C}$. Presl chemical composition and its antioxidant and anti-inflammatory properties. Phytochemistry 107:80-90

Galíndez JDS, Matellano LF, Lanza AMD, Castillo LV (2000) Seasonal variations in the harpagoside content of Scrophularia scorodonia $\mathrm{L}$. Z Naturforsch 55:1035-1037

Generalić I, Skroza D, Šurjak J, Možina SS, Ljubenkov I, Katalinić A, Šimat V, Katalinić V (2012) Seasonal variations of phenolic compounds and biological properties in sage (Salvia officinalis L.). Chem Biodivers 9:441-457

Grausgruber-Gröger S, Schmiderer C, Steinborn R, Novak J (2012) Seasonal influence on gene expression of monoterpene synthases in Salvia officinalis (Lamiaceae). J Plant Physiol 169:353-359

Grulova D, Martino LD, Mancini E, Salamon I, Feo VD (2015) Seasonal variability of the main components in essential oil of Mentha $\times$ piperita L. J Sci Food Agric 95:621-627

Guedes AP, Amorim LR, Vicente A, Fernandes-Ferreira M (2004) Variation of the essential oil content and composition in leaves from cultivated plants of Hypericum androsaemum L. Phytochem Anal 15:146-151

Himanen SJ, Blande JD, Klemola T, Pulkkinen J, Heijari J, Holopainen JK (2010) Birch (Betula spp.) leaves adsorb and re-release volatiles specific to neighbouring plants-a mechanism for associational herbivore resistance? New Phytol 186:722-732

Holopainen JK, Himanen SJ, Yuan JS, Chen F, Stewart CN (2013) Ecological functions of terpenoids in changing climates. Natural products. Springer, New York, pp 2913-2940

Huang W, Bont Z, Hervé MR, Robert CAM, Erb M (2020) Impact of seasonal and temperature-dependent variation in root defense metabolites on herbivore preference in Taraxacum officinale. J Chem Ecol 46:63-75

Hudaib M, Speroni E, Di Pietra AM, Cavrini V (2002) GC/MS evaluation of thyme (Thymus vulgaris L.) oil composition and variations during the vegetative cycle. J Pharm Biomed Anal 29:691-700

Jerković I, Mastelić J, Miloš M (2001a) The effect of air-drying on glycosidically bound volatiles from seasonally collected origano (Origanum vulgare ssp. hirtum) from Croatia. Food Nahrung 45:47-49

Jerković I, Mastelić J, Miloš M (2001b) The impact of both the season of collection and drying on the volatile constituents of Origanum vulgare L. ssp. hirtum grown wild in Croatia. Int J Food Sci Technol 36:649-654

Khodorova NV, Shavarda AL, Lequart-Pillon M, Laberche J-C, Voitsekhovskaja OV, Boitel-Conti M (2013) Biosynthesis of benzylisoquinoline alkaloids in Corydalis bracteata: Compartmentation and seasonal dynamics. Phytochemistry 92:60-70
Krzyżanowska-Kowalczyk J, Pecio Ł, Mołdoch J, Ludwiczuk A, Kowalczyk M (2018) Novel phenolic constituents of Pulmonaria officinalis L. LC-MS/MS comparison of spring and autumn metabolite profiles. Molecules 23:2277

Lakušić B, Ristić M, Slavkovska V, Milenković M, Lakušić D (2011) Environmental and seasonal impacts on the chemical composition of Satureja horvatii Šilić (Lamiaceae) essential oils. Chem Biodivers 8:483-493

Lakušić D, Ristić M, Slavkovska V, Lakušić B (2013a) Seasonal variations in the composition of the essential oils of rosemary (Rosmarinus officinalis, Lamiaceae). Nat Prod Commun 8:1934578X1300800

Lakušić B, Ristić M, Slavkovska V, Stojanović D, Lakušić D (2013b) Variations in essential oil yields and compositions of Salvia officinalis (Lamiaceae) at different developmental stages. Bot Serb 37:127-139

Llorens-Molina JA, Vacas S (2015) Seasonal variations in essential oil of aerial parts and roots of an Artemisia absinthium L. population from a Spanish area with supramediterranean climate (Teruel, Spain). J Essent Oil Res 27:395-405

Loreto F, Pinelli P, Manes F, Kollist H (2004) Impact of ozone on monoterpene emissions and evidence for an isoprenelike antioxidant action of monoterpenes emitted by Quercus ilex leaves. Tree Physiol 24:361-367

Lubbe A, Gude H, Verpoorte R, Choi YH (2013) Seasonal accumulation of major alkaloids in organs of pharmaceutical crop Narcissus Carlton. Phytochemistry 88:43-53

Luis JC, Johnson CB (2005) Seasonal variations of rosmarinic and carnosic acids in rosemary extracts. Analysis of their in vitro antiradical activity. Span J Agric Res 3:106-112

Mahlstein I, Daniel JS, Solomon S (2013) Pace of shifts in climate regions increases with global temperature. Nature Clim Change 3:739-743

Mártonfi P, Repčák M, Mártonfiová L (2006) Secondary metabolites during ontogenetic phase of reproductive structures in Hypericum maculatum. Biologia 61:473-478

Melito S, Petretto GL, Chahine S, Pintore G, Chessa M (2019) Seasonal variation of essential oil in Rosmarinus officinalis leaves in Sardinia. Nat Prod Commun 14:1934578X1986400

Menković N, Savikin-Fodulović K, Savin K (2000) Chemical composition and seasonal variations in the amount of secondary compounds in Gentiana lutea leaves and flowers. Planta Med 66:178-180

Michelakis EC, Evergetis E, Koulocheri SD, Haroutounian SA (2016) Exploitation of Artemisia arborescens as a renewable source of chamazulene: seasonal variation and distillation conditions. Nat Prod Commun 11:1934578X1601101

Milos M, Radonic A, Bezic N, Dunkic V (2001) Localities and seasonal variations in the chemical composition of essential oils of Satureja montana L. and S. cuneifolia Ten. Flavour Fragr J 16:157-160

Nogués I, Peñuelas J, Llusià J, Estiarte M, Munné-Bosch S, Sardans J, Loreto F (2012) Physiological and antioxidant responses of Erica multiflora to drought and warming through different seasons. Plant Ecol 213:649-661

Pacifico S, Galasso S, Piccolella S, Kretschmer N, Pan S-P, Marciano S, Bauer R, Monaco P (2015) Seasonal variation in phenolic composition and antioxidant and anti- 
inflammatory activities of Calamintha nepeta (L.) Savi. Food Res Int 69:121-132

Pacifico S, Piccolella S, Galasso S, Fiorentino A, Kretschmer N, Pan S-P, Bauer R, Monaco P (2016) Influence of harvest season on chemical composition and bioactivity of wild rue plant hydroalcoholic extracts. Food Chem Toxicol 90:102-111

Paolini J, Barboni T, Desjobert J-M, Djabou N, Muselli A, Costa J (2010) Chemical composition, intraspecies variation and seasonal variation in essential oils of Calendula arvensis $\mathrm{L}$. Biochem Syst Ecol 38:865-874

Papageorgiou V, Gardeli C, Mallouchos A, Papaioannou M, Komaitis M (2008a) Variation of the chemical profile and antioxidant behavior of Rosmarinus officinalis L. and Salvia fruticosa Miller grown in Greece. J Agric Food Chem 56:7254-7264

Papageorgiou V, Mallouchos A, Komaitis M (2008b) Investigation of the antioxidant behavior of air-and freeze-dried aromatic plant materials in relation to their phenolic content and vegetative cycle. J Agric Food Chem 56:5743-5752

Peel MC, Finlayson BL, McMahon TA (2007) Updated world map of the Köppen-Geiger climate classification. Hydrol Earth Syst Sci 11:1633-1644

Pěnčíková K, Urbanová J, Musil P, Táborská E, Gregorová J (2011) Seasonal variation of bioactive alkaloid contents in Macleaya microcarpa (Maxim.) Fedde. Molecules 16:3391-3401

Pichersky E, Gershenzon J (2002) The formation and function of plant volatiles: perfumes for pollinator attraction and defense. Curr Opin Plant Biol 5:237-243

Pirie A, Parsons D, Renggli J, Narkowicz C, Jacobson GA, Shabala S (2013) Modulation of flavonoid and tannin production of Carpobrotus rossii by environmental conditions. Environ Exp Bot 87:19-31

Raudone L, Zymone K, Raudonis R, Vainoriene R, Motiekaityte V, Janulis V (2017) Phenological changes in triterpenic and phenolic composition of Thymus L. species. Ind Crops Prod 109:445-451

Roca-Pérez L, Boluda R, Gavidia I, Pérez-Bermúdez P (2004) Seasonal cardenolide production and Dop5 $\beta r$ gene expression in natural populations of Digitalis obscura. Phytochemistry 65:1869-1878

Salido S, Altarejos J, Nogueras M, Saánchez A, Luque P (2003) Chemical composition and seasonal variations of rosemary oil from southern Spain. J Essent Oil Res 15:10-14

Santos-Gomes PC, Fernandes-Ferreira M (2001) Organ- and season-dependent variation in the essential oil composition of Salvia officinalis L. cultivated at two different sites. J Agric Food Chem 49:2908-2916

Schwob I, Bessiere JM, Masotti V, Viano J (2004) Changes in essential oil composition in Saint John's wort (Hypericum perforatum L.) aerial parts during its phenological cycle. Biochem Syst Ecol 32:735-745

Scognamiglio M, D’ Abrosca B, Esposito A, Fiorentino A (2015) Chemical composition and seasonality of aromatic Mediterranean plant species by NMR-based metabolomics. J Anal Methods Chem 2015:258570
Šebrlová K, Peš O, Slaninová I, Vymazal O, Kantorová J, Táborská E (2015) Seasonal variation in alkaloid composition and antiproliferative activity of Stylophorum lasiocarpum (Oliv.) Fedde. Chem Pap 69:698-708

Serralutzu F, Stangoni A, Amadou B, Tijan D, Re GA, Marceddu S, Dore A, Bullitta S (2020) Essential oil composition and yield of a Rosmarinus officinalis L. natural population with an extended flowering season in a coastal Mediterranean environment and perspectives for exploitations. Genet Resour Crop Evol 67:1777-1793

Sharkey TD, Yeh S (2001) Isoprene emission from plants. Annu Rev Plant Physiol Plant Mol Biol 52:407-436

Skrzypczak-Pietraszek E, Pietraszek J (2012) Chemical profile and seasonal variation of phenolic acid content in bastard balm (Melittis melissophyllum L., Lamiaceae). J Pharm Biomed Anal 66:154-161

Skrzypczak-Pietraszek E, Pietraszek J (2014) Seasonal changes of flavonoid content in Melittis melissophyllum L. (Lamiaceae). Chem Biodivers 11:562-570

Slavkovska V, Zlatković B, Bräuchler C, Stojanović D, Tzakou O, Couladis M (2013) Variations of essential oil characteristics of Clinopodium pulegium (Lamiaceae) depending on phenological stage. Bot Serb 37:97-104

Stefanaki A, Cook CM, Lanaras T, Kokkini S (2018) Essential oil variation of Thymbra spicata L. (Lamiaceae), an East Mediterranean "oregano" herb. Biochem Syst Ecol 80:63-69

Stochmal A, Oleszek W (2007) Seasonal and structural changes of flavones in alfalfa (Medicago sativa) aerial parts. J Food Agric Environ 5:84-88

Talić S, Odak I, Martinović Bevanda A, Crnjac N, Paštar M (2019) Helichrysum italicum (Roth) G. Don subsp. italicum from Herzegovina. Croat Chem Acta 92:69-77

Tekel'ová D, Repcák M, Zemková E, Tóth J (2000) Quantitative changes of dianthrones, hyperforin and flavonoids content in the flower ontogenesis of Hypericum perforatum. Planta Med 66:778-780

Thomsen MO, Fretté XC, Christensen KB, Christensen LP, Grevsen K (2012) Seasonal variations in the concentrations of lipophilic compounds and phenolic acids in the roots of Echinacea purpurea and Echinacea pallida. J Agric Food Chem 60:12131-12141

Tuominen A, Salminen J-P (2017) Hydrolyzable Tannins, flavonol glycosides, and phenolic acids show seasonal and ontogenic variation in Geranium sylvaticum. J Agric Food Chem 65:6387-6403

Usano-Alemany J, Herraiz-Peñalver D, Cuadrado J, Díaz S, Santa-Cruz M, Palá-Paúl J (2012) Seasonal variation of the essential oils of Salvia lavandulifolia: antibacterial activity. J Essent Oil-Bear Plants 15:195-203

Varga L, Engel R, Szabó K, Abrankó L, Gosztola B, Zámboriné Németh É, Sárosi S (2016) Seasonal variation in phenolic content and antioxidant activity of Glechoma Hederacea L. harvested from six Hungarian populations. Acta Aliment 45:268-276

Wallaart TE, Pras N, Beekman AC, Quax WJ (2000) Seasonal variation of artemisinin and its biosynthetic precursors in plants of Artemisia annua of different geographical origin: 
proof for the existence of chemotypes. Planta Med 66:57-62

Yang L, Wen KS, Ruan X, Zhao YX, Wei F, Wang Q (2018) Response of plant secondary metabolites to environmental factors. Molecules 23:762

Zidorn C (2018) Seasonal variation of natural products in European trees. Phytochem Rev 17:923-935
Publisher's Note Springer Nature remains neutral with regard to jurisdictional claims in published maps and institutional affiliations. 